Florian Urban, Glasgow School of Art, f.urban@gsa.ac.uk

\title{
Postmodernism and Socialist Mass Housing in Poland
}

10,570 words including notes,

keywords: postmodernism, socialist planning, mass housing blocks, Poland, ŁódźRadogoszcz-East, Poznań-Różany Potok, Kraków-Na Skarpie, Jakub Wujek, Marian Fikus, Jerzy Gurawski, Romuald Loegler

\section{Postmodern-Socialist Mass Housing}

In the 1970s, in Poland as elsewhere in the Eastern bloc, the increasing criticism of, firstly, system-built housing complexes and, secondly, the inflexible structure of the centralised, state-operated construction industry that limited other types of building, led to a deadlock. Few prospects of change were available. Yet postmodernism with its typological concerns and anti-functionalist architectural and planning propositions promised a solution: legible, meaningful and functionally mixed urban spaces inspired by historical precedents that were equally compatible with modern production methods. ${ }^{1}$ Nonetheless, the translation from theory to practice was anything but straightforward.

Based on archival documents, contemporaneous publications, and interviews with the protagonists, this article will trace the history of these postmodernist mass housing complexes. It will show that these projects were first influenced by late modernist ideas, in particular by structuralism such as that exemplified in the work of Aldo van Eyck, Piet Blom, or Candilis/Josic/Woods, or the ideas developed by Oskar Hansen and his followers. Only at a later stage did they absorb postmodernist theory from both national and international sources. The story of Poland's postmodernist housing complexes was thus one of modernist architecture's gradual modification and adaptation.

In contrast to most socialist mass housing, Polish postmodernist complexes were "architect-built." They resulted from the efforts of particular designers who asserted themselves against the socialist technocracy and realised innovative forms within a system established to yield mass-produced, de-individualized forms. As such they were an outcome of inventive individuals who took advantage of the leeway that the declining socialist regime, at least in certain cases, gave to individual creativity.

Poland's postmodernist architecture has become the subject of increasing scholarly interest, particularly among Polish scholars. ${ }^{2}$ Recent studies have focused on different aspects of architectural production under the socialist regime, including postmodernist churches and residential buildings sponsored by the fledgling market economy. ${ }^{3}$ The latter forms the background to this article which will lay out the framework of domestic and international influences in which the short-lived encounter between postmodernism and socialist mass housing evolved.

[figure 1 near here]

Examples of such projects can be found in many Polish cities. This article presents three developments: Radogoszcz-East in Łódź (1979-1989, designed by Jakub Wujek, Zdzisław Lipski, and Andrzej Owczarek), Różany Potok in Poznań (1978-2010s, designed by Marian Fikus, Jerzy Gurawski), and the $\mathrm{Na}$ Skarpie Estate in Kraków-Nowa Huta (1987-95, designed by Romuald Loegler, Wojciech Dobrzański, Ewa Fitzke, and Michał Szymanowski) (figure 1). As well as being particularly prominent developments, they were united by a common approach. Each of these examples were planned as dense urban environment in which a fixed street pattern provided the opportunity for changeable buildings with diversified design and mixed use. At the same time all of them, like their predecessors in the 1960s, were greenfield developments located on urban peripheries. While all three were planned within the institutions of the centralised socialist construction industry, only one of them, Radogoszcz-East, was built as a mass housing complex from prefabricated panels, featuring repetitive, five-to-ten storey blocks. The $\mathrm{Na}$ Skarpie Scheme was eventually carried out as a block development form with both prefabricated and customised elements. Różany Potok, which was repeatedly re-planned and mostly built after the end of the socialist regime, came to be realized as a heterogeneous development of typologically diverse three-to-five-storey perimeter block buildings.

The principal architects, Jakub Wujek (1937-2014), Marian Fikus (b. 1938), Jerzy Gurawski (b. 1935), and Romuald Loegler (b. 1940) had a long track record of functionalist design before committing to postmodernist forms. None of them, at that time, was an outspoken 
modernist renegade. Instead they belonged to the generation educated in the spirit of progress and modernization that had been trained to produce Soviet-style neighbourhood units that combined system-built residential blocks with schools, shops and leisure facilities. There is little evidence of strong intellectual or artistic breaks in their careers, and much more of incremental change and of gradual modifications in their outlooks. All of them at some point took up basic postmodernist principles, such as ornamentation and historic references, as well as the creation of corridor streets and squares formed by perimeter block buildings. All projects evolved over a long time and were built differently from what was proposed in the first plans.

All three projects were manifestations of the great endeavour that had first instigated modernist mass housing estates: the fight against exacerbating housing shortage. The large-scale production of flats was a constant priority among the leaders of the ruling Polska Zjednoczona Partia Robotnicza (PZPR, Polish Unified Workers' Party). They were produced in what was colloquially referred to as fabryki domów ("house factories"), large state-operated enterprises first set up in the late 1950s, which produced system-built concrete panels that subsequently were assembled into standardized blocks. The first were "closed systems" that could be put together to form one particular type of block. "Open systems" of prefabrication, such as Szczecin or WB 70, were introduced in the 1970s. Various housing types could be produced from the same panels. However, there was little overall aesthetic variation. At a time when similar prefabrication programmes were mostly phased out in Western Europe, panel construction rose to unprecedented levels in Poland, and by the early 1980 s it accounted for 70 per cent of newly produced dwelling units. ${ }^{4}$ There is strong evidence that this situation resulted from path the industry's dependency upon a limited supply-chain rather than on the built results, and that the socialist rulers were unable to substantially reform the prefabrication industry without damaging the entire state-directed construction system.

This article presents several attempts to diversify and "humanise" the unloved blocks which took place as the socialist regime progressively declined. This was marked by an aggravated economic crisis in the late 1970s under Party leader Edward Gierek, and waves of popular protest connected with the activities of the Solidarity Trade Union, which peaked in 1980/81. The upheavals which followed the declaration of martial law and the takeover of General Wojciech Jaruzelski in 1981, as well as the economic reforms initiated in 1980 gradually introduced market elements (a fully-fledged market economy was established only in December 1988 through the "Wilczek Law"), and which continued after the collapse of the socialist regime in 1989 , were also significant. ${ }^{5}$

At that time criticism of prefabricated panel construction was just as widespread in Poland as it was in other socialist countries and in Western Europe. ${ }^{6}$ In 1985 and in spite of the censorship levelled against it, the official journal Architektura openly suggested "Responding to the question how to modify the 'house factories' in order to raise the level of residential architecture the basic conclusion is: the organizational structure of the panel factories must change." 7 Such change never came. In socialist Poland there was no comprehensive reversal of the tower-in-the-park paradigm. Neither was there a resolution like that of the East German Politburo, which in 1982 mandated future housing developments to be carried out preferentially on gap sites between historical five-storey tenements in the city centre, ${ }^{8}$ or a tradition of designing panel blocks in regional variations as in the Soviet Union. ${ }^{9}$ In light of political and economic difficulties the Party approach to matters of construction became patchy and makeshift, and lacked the consistence of official architectural policy during the 1950 s and 1960s. The socialist rulers continuously supported panel construction, but at the same time encouraged any alternative approach that promised to increase the output of housing units or diminish criticism against the monotonous panel blocks.

The story of Poland's postmodernist blocks is therefore one of an uneven and, in terms of the goal of "humanising" the mass housing districts, unsuccessful struggle. The few realised projects nonetheless stoked an evolving discourse on postmodernist architecture and urbanism, and channelled forces of innovation that would gain significance in the years to come. 
Łódź-Radogoszcz-East and the Spirit of Structuralism

Radogoszcz-East, located on the northern periphery of Łódź (built 1979-1989, and designed by Jakub Wujek, Zdzisław Lipski, Andrzej Owczarek), was one of the most prominent Polish attempts to give socialist mass housing a human face. It aimed, as appropriately summarised in the obituary of the lead architect Jakub Wujek, an "inhabitant-friendly city from blocks. ${ }^{110}$ As such, it was part of a project to convert Łódź, at the time Poland's second largest city (now third largest), into a booming modern metropolis, which sought to shed its association with smoke-belching textile mills, whilst simultaneously reconnecting the city with its past grandeur. The scheme boasted ornamented façades, a legible arrangement of buildings, a prominent central square (Plac Słoneczny, "Sunny Square") (figure 2), and mixed-use zones featuring shops on groundfloors which reproduced many urbanistic principles of central Łódź or similar nineteenth-century cities. Corners and passageways between the blocks were modelled after the small streets and alleys of a pre-modernist town, and equipped with benches and lawns. Public, semi-public and private areas were clearly demarcated. The small semipublic spaces next to the buildings, referred to as kameralne ("chamber-like"), were a counterproposition to the wind-swept voids in other mass housing estates, and a victory against one-size-fits-all regulations that mandated wide distances between buildings. ${ }^{11}$ (figure 3) Plac Słoneczny was laid out like a baroque city square, surrounded by representative perimeter block buildings and provided stately views along radial axes. The façades displayed colourful ornaments, which as "identity devices" were aimed at legibility and distinction (figure 4$).{ }^{12}$

[figure 2, figure 3, figure 4 near here]

At the same time the project was also based on functionalist principles. Like most new neighbourhoods in Poland and elsewhere in the Eastern bloc, also Radogoszcz-East was designed as a mikrorayon (micro-district), the Soviet version of the self-sufficient residential quarter theorised by Le Corbusier, Clarence Perry, Leonid Sabsovich and others in the early twentieth century. It was a greenfield development on the periphery, and sheltered from through traffic (figure 3). The programme was based on scientific calculations regarding the inhabitants' needs, which included a predicted number of shops, schools, and recreational facilities, but no offices or industry, as inhabitants were expected to work elsewhere in the city. Radogoszcz-East thus upheld some aspects of modernist urban design while breaking away from others.

The planning process was similar to that of other Polish mass housing estates. Like most residential schemes at the time, Radogoszcz-East was commissioned by a housing association, the 'Lokator' "Workers Housing Association" which to date administers the complex under a slightly different organizational structure. Under socialism it was a Łódźbased public institution tightly controlled by nationwide planning institutions, in particular by the Warsaw-based Centralny Związek Spółdzielczości Budownictwa Mieszkaniowego (CZSM - Central Organization for Cooperative Housing Construction). ${ }^{13}$ The housing association determined the number of flats and social facilities such as schools and culture houses, but was bound by the regulatory framework of planning provisions, building standards and available materials (mostly prefabricated parts). Hence, despite the client's local base and nominal independence, the leeway for individual design was very limited.

Like mass housing estates in all socialist countries, Radogoszcz-East was designed by architects employed with large, state-operated design firms. Jakub Wujek, Zdzisław Lipski, Andrzej Owczarek and their colleagues worked for the design firm Miastoprojekt Łódź, a local institution subordinated to the Warsaw Ministry of Construction. Once their urban plan was accepted they were transferred to Inwestprojekt Łódź, the local branch of the nationwide design firm Inwestprojekt. Inwestprojekt Łódź was subordinated to the CZSM. Like the Inwestprojekt branches in other Polish cities, it was the designated architectural office for housing associations.

It was within these positions that the architects managed to secure a comparatively high level of creative freedom. Miastoprojekt Łódź was a technocratic public body and not an independent institution comparable to a capitalist architectural practice. But the fact that it worked for different clients and engaged in organised competitions nonetheless created a certain degree of particular identity and the desire to promote one's own designers, which Wujek and his team were able to use to their advantage. Miastoprojekt Łódź thus provided 
them with opportunities to develop their ideas in the context of exhibitions and publications, even though only a few of them were eventually implemented.

Construction of the scheme began in 1979 and was largely completed by the end of the socialist regime in 1989. Many of the social facilities were built, including schools, kindergartens and shops. Somewhat unexpectedly for a socialist housing complex, a church was planned on Aleja Romantyczna and Sobótki (first shown in a 1986 plan). It was subsequently built in a restrained neo-traditional style as the Holy Sacrament Church (1987-99, Jakub Wujek and Zdzisław Lipski), and exemplifies the architectural vocabulary the lead designers were ready to use when they were not restricted by the state-led prefabrication industry (figure 5). ${ }^{14}$

[figure 5 near here]

Much evidence suggests that it was the architects, rather than the client or the local Party leaders, who were the driving forces in the scheme's unusual design. This aligns with the observation that in Poland, in contrast to other socialist countries, Party influence on the architectural profession was limited. An architect's career usually did not rely on Party membership, and even voivodeship chief architects or designers of government buildings were sometimes not Party members. ${ }^{15}$ The Łódź Party committee, like its counterparts all over the country at the time, was rather indifferent about specific architectural design, and ready to support any measure that promised to provide housing and calm down popular protest. ${ }^{16}$ There is also no evidence of a stylistic influence of the leading local Party functionary, mayor Józef Niewiadomski (in office 1978-85), despite the fact that he was heavily involved in local building activities and later became Polish Minister of Construction. ${ }^{17}$

The architects, on the other hand, vocalised their ideas. At the time, lead architect, Jakub Wujek, was already a well-established designer in his forties, strong-minded and experienced in difficult negotiations. As one of just a few Polish architects at the time he had also spent time abroad. After graduating from Gdańsk Politechnika he worked for the office of Osmo-Lappo in Helsinki from 1963-64. In addition to familiarizing him with the latest trends in Scandinavian architecture, this also taught him management skills he would not have been able to learn in a socialist context. ${ }^{18}$ From 1967 on he formed a productive collaboration with Zdzisław Lipski. When they were later joined by Andrzej Owczarek, Krystyna Greger and others, they formed their own design unit, Pracownia 3 (Studio 3), at Miastoprojekt Łódź. Photos from these years show him as a fashionable young man wearing John-Lennon glasses and individualistic, hippie-inspired clothes that were not usually seen in bureaucratic socialist environments. ${ }^{19}$ In Pracownia 3, Wujek and his colleagues worked on panel-built housing complexes such as Teofilów C (built 196669), and at the same time developed experimental projects and ideas for exhibits and publications. $^{20}$

[figure 6 near here]

The most unusual aspect in the design for Radogoszcz-East derived from these ideas: the plan regulacyjny (master plan), which was worked out in 1978 (see figure 6) ${ }^{21}$ For the first time in a socialist estate, urban planning and architecture did not result from an integrated design process, but, like in nineteenth-century neighbourhoods, were carried out in two different phases. The block plan was created first and later completed with buildings. The buildings were supposed to display variations over the common theme laid out in the plan. This was to allow for a better connection of buildings and streets (in contrast to the much-criticized "scattered blocks"), and the genesis of a cohesive urban fabric. ${ }^{22}$

The process came to be widely used in the "fruit salad estates" in early-twenty-firstcentury Europe in which buildings of different shapes form part of an overall composition synchronised by the plan. ${ }^{23}$ Examples include Vienna's Aspern Lake Town (begun 2007, master plan by Johannes Tovatt, buildings by Einszueins, Scheifinger \& Partner, Walter Stelzhammer and others) to Wrocław's much-reviewed Nowe Żerniki scheme (begun 2014, Piotr Fokczyński, Zbigniew Macków, Anna Misiura, and others), the inheritor of the 1920 s German Werkbund schemes.

Among the most important influences for Radogoszcz-East were nonetheless not nineteenth or early-twentieth-century urbanism, but rather late modernist theories 
brought forward in the 1960 s and 1970 s by the Dutch structuralists, as well as innovative approaches developed at the time in Sweden and West Germany. ${ }^{24}$ Along these lines the Polish architects aimed not at a wholesale rejection of functionalist modernism, but at its reform and modification. Wujek and Lipski called for residential complexes to emerge from a creative interplay between "continuous" and "changeable" elements, as stated in their sketches for Teofilów $C$ in Łódź (which was eventually built as a rather uninspiring tower block scheme). ${ }^{25}$ Their colleague Andrzej Owczarek promoted "replaceable" elements, such as portions of flat plans or building sections, which were to be included into the design of entire buildings as adaptable variations over the same theme. ${ }^{26}$ (figure 7 ) These ideas echo the influence of structuralist thinking, as for example realised in Aldo van Eyck's Amsterdam Orphanage (1958-60) or Piet Blom's Kasbah Housing in Hengelo (1969-72), as well as famous unrealised city extensions, such as Kenzo Tange's Tokyo Bay Plan (1960) or Jaap Bakema's Pampus Plan (1964). ${ }^{27}$ These and similar ideas were widely discussed in Wujek's circles. ${ }^{28}$

[figure 7 near here]

Another significant influence was Skarpnäck City in Stockholm (1980-90, master plan by Leif Blomquist, buildings by Ralph Erskine, Arken, FFNS Architects and others). Owczarek gained first-hand experience of the genesis of this dense, block-based development of 3,300 flats during several visits in the $1970 \mathrm{~s} .{ }^{29}$ Unlike in the structuralist examples, the harmonic "variation over the same theme" was achieved through different designers: a master planner providing rules regarding street plan, volumes, and façades, and diverse architects developing their ideas on the basis of these rules - precisely the process Wujek later praised as postmodernism's key contribution to Polish architecture. ${ }^{30}$

This process was also a basic principle of the International Building Exhibit in West Berlin (1979-87), usually referred to by its German acronym IBA, which had similar influence on Wujek and his colleagues. The IBA's declared goal was the integration of new architecture into the historical urban fabric. Connected with the IBA were the debates on architectural language and typology, which at the time were also widely discussed in Poland. Wujek and his colleagues specifically developed their design from an "architectural language" composed of typological precedents. Basic volumes and added elements such as accentuated corners result from an analysis of historic models, such as bay windows and sentinel towers from the renaissance era. ${ }^{31}$ (figure 8 ) The principle of assembling buildings along a central, traditional square are reminiscent of Rob Krier's urban design, as can be seen in the drawings that show the squares south of the street Romantyczna realized in 1985 (figure 9). ${ }^{32}$

[figure 8, figure 9 near here]

How was the unusual design realized within the inflexible structures of the socialist construction industry? Much suggests that individual skills and personal contacts played a crucial role. Even before construction started the architects had to convince the city administration to relocate a high-voltage power line as well as the thoroughfare Aleje Sikorskiego to correspond with their idea of an integrated urban fabric. ${ }^{33}$ The director of the Housing Association Lokator had close ties to the Warsaw-based central organisation of housing associations CZSM, which helped the master plan to be approved. ${ }^{34}$ Subsequently, the Chief Architect of Łódź gave his assent, and eventually the different municipal construction authorities did too.

Negotiations with the "house factory," the producer of prefabricated parts, were the most difficult part of the process. Owczarek had closely observed the attempts to build smallscale pedestrian alleys from modified panel buildings in the Warsaw-Ursynów estate (designed by Marek Budzyński, Jerzy Szczepanik-Dzikowski and others, begun 1971). He had met the authors during his studies at Warsaw Politechnika, and remembered their negotiations as a "terrible and exhausting fight" with the "house factories." In RadogoszczEast, he and his colleagues therefore opted for a different strategy. ${ }^{35}$ They accepted the standardized building plans and shapes the "house factory" had on offer, and instead focused on a different distribution of the buildings and public spaces. Modifications were carried out only in the details, for example added loggias, balconies, accentuated entrances, and small, individualised pavilions on the corners, as well as parapet walls and other concrete ornaments. (figure 10, figure 11) In a climate in which system-built, industrialised construction was increasingly criticized and the directors of the panel 
factories found themselves on their back foot, they were ready to compromise on standardized volumes and added ornaments. ${ }^{36}$

[figure 10, figure 11]

In retrospect Wujek praised the modifications as manifestations of political opposition that supported his broader fight against the regime. ${ }^{37}$ However, it is significant that he had simultaneously become the city's most influential architect and that he had retained this position under martial law; to do so he must have been sufficiently cautious in voicing oppositional thoughts. His success probably relied on the right mixture between acquiescence and resistance, as well as on his good negotiation skills with both Party and non-Party actors. Somewhat consistently with this approach the results were characterised by a certain ambiguity: they were firmly rooted in the socialist system of central planning and standardized construction, whilst at the same time they pushed mass housing design to a new level.

Wujek and Lipski documented their struggle with the socialist institutions in a surprisingly critical article, which despite censorship was published in the official journal, Architektura. They openly complained about the "house factory". It was "one of the 'toughest' local firms which dictated conditions that could not be rejected." 38 The latter were consistent with the Szczecin building system, which allowed for two possible building types and was used for the first group of buildings (the school buildings north of the street Syrenki, built from 1979 to 1980), and the similarly inflexible W-70 technology for the second group of buildings (south and west of the school buildings, built between 1980 and 1981). ${ }^{39}$ (figure 12)

[figure 12 near here]

Only from the third group of buildings onwards the architects managed to fully realise the clear division of public and private space foreseen in the master plan. In the third group, situated around the intersection of Wiankowa and Wodnika, as well as in other subsequent portions, this was achieved through little walls, gardens, and small doors. The fourth group, situated south of Romantyczna, which was designed between 1980 and 1982 and built from 1984 onwards, was the most important realization of the "square model." In the seven groups of buildings that were built in the Szczecin prefabrication system all entrances lead to slightly oblong central squares. In addition, the division between public (street), semi-private (square/courtyard) and private (building) is clearly legible. The architects worked out clear guidelines on access roads, greenery and street furniture.

The central square Plac Słoneczny, originally called Plac na Glinkach, was part of the fifth phase, and built from 1985 (figure 13). It is arguably the most convincing portion of the scheme with regard to the goal of creating meaningful urban space from $\mathrm{W}-70$ panels. Plac Słoneczny reproduced important aspects of a traditional square: a contained public space limited by shop fronts, and a series of representative façades achieved by sparsely used ornamentation and vertical structuring elements such as balconies and loggias. This urban ensemble is believed to derive from variations over a common theme similar to a nineteenth-century street.

[figure 13 near here]

At the time the reception of the Radogoszcz-East scheme was largely positive, and existing evidence suggests that the architects perceived their approach as a nationwide solution for improving the unloved panel block districts. In 1985 they prepared a similar proposal for the Janów district in eastern Łódź. ${ }^{40}$ Given the progressive erosion of the centrally planned economy, however, the proposal remained unrealised.

The positive reception of this "postmodernist block scheme," as well as of postmodernist currents in general, also has to be seen in the context of state control and enforced conformity, against which any attempt at diversity could be seen as a rebellious act. As Wujek put it thirty years later, "building a little different was already very much, and this was postmodernism." 41 Non-conformism lay at the bottom of his gentle anti-modernist criticism. In 1980, at the peak of anti-government protests in Poland, he called for a "return to decorum" against as the monopolized, state-organised architecture that "favoured only claritas." ${ }^{2}$ In 1983, in his opus magnum "Myths and Utopias of TwentiethCentury Architecture," he criticizes the "myths" and "barriers" of modern architecture, in particular techno-fetishism and the belief in design as a source of happiness, while at the 
same time accepting the modernist canon as such. ${ }^{43}$ And in 1986 he compared latetwentieth-century attacks on modern architecture to the architectural sea change around 1800 that accompanied the transition from feudal to bourgeois rule. ${ }^{44}$

It would be too simplistic to interpret Radogoszcz-East as act of resistance against the socialist regime. After all, as was mentioned earlier, the design evolved within the socialist planning apparatus and was firmly rooted in some of its most basic principles, including the fostering of urban cohesion. But much suggests that positive perception of the scheme, as well as of the underlying postmodernist currents in general, relied on its association with the values of diversity and flexibility that would eventually transcend the socialist regime.

Poznań-Różany Potok and the Revised City Extension

A similar development can be seen in the Różany Potok scheme in Poland's fifth largest city of Poznań (begun in 1978 and mostly finished in the 2010s, designed by Marian Fikus and Jerzy Gurawski). Różany Potok was part of a city extension in the northern Morasko district, which developed over three decades, and evidences the incremental change of design principles. Like Radogoszcz-East, the scheme received important input from structuralist thinking and eventually became a prime example of postmodernist architecture and planning.

As with the designers of Radogoszcz-East, the architects of Różany Potok are not easy to characterize in relation to modernism and postmodernism. Marian Fikus and Jerzy Gurawski met while working for the municipality of Opole in southwest Poland and formed a team when they were both in their mid-twenties. Gurawski had studied at Kraków Politechnika and originally worked as a theatre set designer, developing his ideas of space as a set of relations rather than a fixed entity. Fikus had graduated from Wrocław Politechnika. In 1976 they both moved to Poznań, when after winning the competition for the Różany Potok area the Chief Architect of Poznań, Jerzy Buszkiewicz, offered them a job at the municipal design firm, Miastoprojekt Poznań.

At the time they had established a reputation not with built projects but with a series of prize-winning competition entries for the re-planning of small towns such as Kędzierzyn, Głogów or Włocławek. These were committed to the CIAM debates over the "heart of the city" - block-like public buildings that are carefully assembled around pedestrianized decks and squares and serviced by car parks and motorways-a rather abstracted form of the traditional market square, and not one that was particularly sensitive to the historic urban fabric.

The task in the Różany Potok area was to build a new campus for the prestigious Adam Mickiewicz University in Poznań comprising infrastructure and buildings on approximately 300 hectares, which were to accommodate about 30,000 students and 4,000 employees. ${ }^{45}$ The new neighbourhood was to evolve on the northern periphery, in a largely unbuilt area amidst pine forests, lakes and streams-the largest was the name-giving Różany Potok (Rose Burn). The university served as the client. The brief was firmly rooted in the principles of functionalist planning: separation of traffic-the university was to be served by both a motorway and a new tramway line, and creation of two self-contained areas; a university area with buildings for teaching and administration; and a residential district for teachers and employees that was administered by the university housing association. The latter was the future Różany Potok scheme. ${ }^{46}$ The high prestige of the project from the very beginning opened up possibilities unavailable for other new districts. Design was based on a closed competition organised in 1974 by the Stowarzyszenie Architektów Polskich (SARP - Polish Architects' Association), to which Fikus and Gurawski were invited for their reputation as visionary urban designers. The project received high public attention, and the organisers from the beginning were open to innovative solutions.

[figure 14 near here]

Fikus's and Gurawski's prize-winning plan was inspired by the most famous university campuses in Western Europe at the time (figure 14). Models included the influential structuralist Free University in West Berlin (1967-72, Georges Candilis, Alexis Josic, Shadrach Woods) and particularly the Ruhr University in Bochum (1964-74, Helmut Hentrich, Hubert Petschnigg), which they had visited in the early $1970 \mathrm{~s} .{ }^{47}$ Accordingly, Fikus's and Gurawski's plan was a sequence of connected low-rise buildings intersected by 
pedestrian paths and surrounded by motorways and cloverleaf junctions as well as park spaces and greenery. The northern area featured student residences, which were clustered together in a half-hexagon form. The southern area was reserved for university buildings which, like in Bochum, were assembled around a polygonal square and serviced by a grid of orthogonal footpaths. Like many megastructural plans at the time, the square was designed as a deck at first-floor level and reserved for pedestrians; the lower storey at street level featured the tramway link. Towards the east the square was connected to a pedestrian street in east-west direction, which served as the university area's spine. In retrospect, Fikus called this "integrative esplanade" (now largely a car park) the central meeting place and the most important aspect of the proposal. ${ }^{48}$

The structuralist influences are just as obvious as in the early drawings of the RadogoszczEast designers, although a little less prominent. Fikus's and Gurawski's plan evolved around a central network of infrastructure, which was potentially expandable and adaptable. The buildings could be changed without affecting the structure. At the same time the sequential interior courtyards and the central position of the square already pointed to a line of thinking leading into postmodernist urbanism. Following a structuralist logic they could be developed into typological "variations over the same theme," including historically inspired perimeter-block buildings like those that were eventually built.

There is also a noticeable influence from Oskar Hansen's theories about "open form." 49 Hansen (1922-2005), who in the postwar decades was arguably Poland's most influential urban theorist, developed his ideas about open, modular forms that evolve around connective public spaces. One of his best-known projects, the Przyczółek Grochowski complex in Warsaw (1969-74, Oskar Hansen, Zofia Hansen), shares with Fikus's and Gurawski's plan the public courtyards created by orthogonal buildings with "internal" and "external" faces, as well as the modular structure that is potentially expandable along a linear direction (figure 15).

[figure 15 near here]

These themes were developed in subsequent proposals. The second plan from 1976, which was worked out after Fikus and Gurawski had won the competition, already had a different feel (figure 16). The two districts were expanded. The "integrative esplanade" in the university district became more prominent. At the same time the residential district now had aspects of a traditional street pattern. The decks were still part of the proposal, but the conspicuous motorways became downscaled. Both decks and motorways would disappear in subsequent plans. The division between a fixed network of streets and infrastructure on the one hand, and potentially changeable elements that were connected to them on the other, was still the guiding design principle.

[figure 16 near here]

The cornerstone of the new campus was laid in 1978, but due to the mounting economic crisis and the political upheavals connected with the Solidarity protests construction soon stalled. After four years the architects publicly spoke of their frustration in light of "wasted hours, days, months and years." ${ }^{50}$ In the following they nonetheless developed further specifications. Construction continued at a slow pace, and the first university buildings went up in the 1980s. One of the earliest was Fikus's and Gurawski's design for the Physics, Acoustics and Mathematics Building (built 1978-94, modified in 1999), by now an icon of Polish postmodernist architecture (figure 17). The first drawings from 1976 show a late modernist four-storey structure on a grid around repeating quadrangular courtyards similar to those of Candilis/Josic/Woods' Free University in West Berlin. When the first portion was finished in 1991, the building had become significantly more postmodern thanks to features such as brick-faced arches, circular windows, and pyramid-shaped glass roofs. ${ }^{51}$ In its current state it is dominated by a glazed green entrance built around a steel tube scaffolding, the building consists of different geometric volumes that are visually separated through brickfacing and glazing. Conspicuous round and half-round windows structure the façade; there are ornamental brick parapet walls and different roof shapes. There are similarities to the industrial aesthetics of James Stirling's Faculty of History Building at Cambridge University (1968) as well as Aldo Rossi's historical typologies.

[figure 17 near here]

In the first plans there was little information about the residential buildings. The drawings nonetheless suggest that they were to be system-built structures from prefabricated 
panels. With the progressive modification of the plans the outlines became more ambiguous, and by the mid-1980s there were clear neo-traditional elements. It seems that the changes were not the outcome of external pressure, but were rather carried out as a result of further specification and reflected the architects' changing preferences. In retrospect both architects stressed their continuous concern with communicative urban spaces throughout their careers. ${ }^{52}$ While modifying the Poznań University plan, they also designed one of the icons of Polish postmodernist architecture, Our Lady Queen of Poland Church in Głogów (built 1985-89). It is a central-plan building constructed with brick and wood, decorated with elements from historic folk architecture, that is topped with a wooden belltower, and enclosed by a surrounding archway. Financed by the Catholic Church, and thus by a client with fewer restraints regarding forms and materials, the building allowed the architect to develop themes that would progressively also become important in the Różany Potok scheme: a concern with small-scale meeting spaces and place-specific identity.

In 1984 the architects worked out the plan realizacyjny (implementation plan) that specified the residential area, and which at the time was first referred to as the "Różany Potok scheme." It covered approximately 16 hectares of the 300-hectare plan (figure 18). Northeast of the Różany Potok scheme proper there was also a small portion carried out by the housing association "Uniwer," which was built between 1985 and 1990. From the 2000s onwards the wider neighbourhood also included developer-built housing.

In the area covered by the "implementation plan" buildings were now ordered in a traditional, orthogonal block scheme with tree-lined streets and block perimeter buildings. Two types dominated: directional buildings with façades towards the street and backsides with gardens towards the alley, and open courtyard buildings erected around a landscaped inner part of the block. At the centre of the development there was a quadrangular square referred to as rynek ("market square"), which was intersected by two orthogonal streets and surrounded by symmetrical blocks. Its southern side opened to a wedge-shaped park with a vista towards the brook.

[figure 18 near here]

The first building types were also developed in the late 1980s. As the Uniwersytecka Spółdzielnia Mieszkaniowa Różany Potok (Różany Potok University Housing Association) opened to the general public, the residential portions were no longer designed exclusively as staff housing, although there was still a significant share of university employees among the future inhabitants. ${ }^{53}$

At the time the architects were already able to take advantage of the new materials that the fledgling market economy offered to Polish builders, and unlike the designers of Radogoszcz-East no longer had to rely exclusively on prefabricated panels. As a result, the design became significantly more varied than that of Radogoszcz-East. There were clear influences from the international currents at the time, particularly the West Berlin IBA. Next to four-storey walk-ups with historically inspired façades, loggia balconies, and ornamental columns on the groundfloor, there were what the architects in a 1988 plan referred to as szeregowce zdwojone ("double terraces") (Figure 19). These were threestorey terraced houses with two interlocking self-contained flats on the groundfloor/first floor, and on the first/second floor, which can be accessed through separate entrances (figure 20). With their representative, historically-inspired façades they were an urban version of the suburban terraced house. These and other buildings were completed after the end of the socialist regime, now mostly by Fikus's office and without Gurawski's participation.

[figure 19, figure 20 near here]

In the late 2010s Różany Potok presents itself as a quiet, mixed neighbourhood, which despite its peripheral location has an urban rather than suburban feel. This is due to its relative density and perimeter block buildings, despite the fact that some of its key locations still remained unfinished, including the "market square" or the wedge-shaped park. On the other hand, the mixed-use four-storey walk-ups were largely completedtoday one houses Fikus's office. (figure 21) Together with the ornamented rows of twoand three-storey residences they form a harmonic entirety (figure 22).

[figure 21, figure 22 near here] 
The convoluted design history shows that the postmodernism of the Różany Potok scheme originated from concerns with structure and community. The latter were integral to the late modernist debates on both sides of the Iron Curtain. The project exemplified how structuralist and megastructural influences over the course of three decades were modified into a development based on postmodernist planning principles such as perimeter block construction, historically-inspired typology, and functional mixture.

Kraków-Na Skarpie and the Memories of Socialist Realism

The third example is the Centrum E scheme in Kraków-Nowa Huta (1987-95, Romuald Loegler, Wojciech Dobrzański, Ewa Fitzke, Michał Szymanowski), usually referred to as Osiedle Na Skarpie ("complex on the escarpment"). (figure 23) Designed a decade after Radogoszcz-East the set-up was already different and reflected the economic reforms carried out in the $1980 \mathrm{~s}^{54}$ The client was still a large, highly regulated housing association named Budostal. However, the designer was not a big municipal office as in RadogoszczEast or in the early phase of Różany Potok. Rather the Pracownia Usług Architektonicznych (Studio for Architectural Services), which was run by the Kraków branch of the architects' association SARP, operated with a higher degree of independence and was, for example, allowed to draw up contracts with private architectural firms. ${ }^{55}$

[figure 23 near here]

The lead architect Romuald Loegler was one of the most innovative designers of his time and also one of the few who accepted the label "postmodernist." ${ }^{56} \mathrm{He}$ was educated at Kraków Politechnika and soon became the assistant of his professor Zbigniew Kupiec (1905-90), whose ideas of a modernism with classical rules and integrated folk elements were an important influence. ${ }^{57}$ Like Jakub Wujek, and unlike most Polish architects of his generation, Loegler also managed to gain work experience abroad. Already as a student he won scholarships to travel to France and Finland. In 1973 he spent two years in Vienna, where he studied at the Technische Hochschule under Karl Schwanzer and subsequently absorbed influences from Schwanzer's sophisticated use of geometrical volumes, as exemplified by the famous St Jadwiga Church in Kraków's northern Krowodrza Górka district (1983-89, Romuald Loegler and Jacek Czekaj), and which brought him national acclaim. The building showed a Stirling-style play with volumes and typologies with no obvious historic references. He used similar approaches in the 1981 design for a mediumrise housing block on the corner of the streets Nowowiejska and Kazimierza Wielkiego in Kraków. ${ }^{58}$ When designing the Na Skarpie scheme Loegler headed one of the first privately run architecture offices in Kraków and, in contrast to most of his colleagues, maintained close ties with the international architectural world. He was also the driving force behind the first Biennale of Architecture, which took place in Kraków in 1985.

From 1970, and again in the 1980s, Loegler was part of a team of Polish architects working in Syria. The influence of his and his colleagues' Middle Eastern experience on the course of postmodernist architecture has been the subject of recent research. ${ }^{59}$ Typological variation as a design principle, which is crucial in the Na Skarpie scheme, was already visible in his 1984 project for the Commerce and Service Centre in Aleppo/Syria. Loegler himself acknowledged such influences, pointing out that his work in Syria forced him to think about "the persistence of the urban structure, which paralleled the evolution of architectural language. ${ }^{\prime 60} \mathrm{His}$ statement not only points to typological "variations over the same theme," but similarly to the tension between continuous structure and changeable elements that lay at the bottom of the early master plans for both Radogoszcz-East and Różany Potok.

The original programme for the Na Skarpie Estate showed little difference to that of a typical socialist mass housing estate. ${ }^{61}$ The stated goal was to build about twenty 4 to 6 storey residential buildings, facilities for commerce and services, including a housing association office, a clothing store, a photo studio, a watchmaker's workshop, a hairdresser, a Pewex imported goods shop, a Cepelia folk art shop, and a café. The buildings were to be erected from Żerań large blocks, a prefabrication system developed in the 1960s. And yet the result was surprisingly different. The Na Skarpie scheme came to be a colourful ensemble of unexpected typological variety. Buildings were loosely modelled after historical urban blocks and often displayed classically structured façades with decorative details such as loggias, rounded balconies, and ornamentation. 
An important reference was the immediate surrounding. The Na Skarpie complex was an addition to Poland's most prestigious new town Nowa Huta, which was begun in 1949 for about 300,000 inhabitants around a steel processing plant eight kilometres east of Kraków's city centre. Nowa Huta was designed to be a socialist model town for proud working class professionals, in contrast to the "bourgeois" former royal residence and merchant city of Kraków. At the same time it was a showcase of the Stalinist neoclassical style in architecture and urbanism that was modelled on 1930s Moscow and referred to as "socialist realism" or "socrealism." Ornamented perimeter block buildings were arranged around the Plac Centralny (Central Square, laid out in 1950); social facilities such as schools, cinemas and culture houses boasted similar representative façades. The plan was characterized by a traditional block structure, the primacy of the streetscape, and the clear demarcation of public and private spaces. The construction of Nowa Huta spanned more than three decades, and many of the later neighbourhoods incorporated functionalist influences that stood in contrast to the original neoclassical principles. The Na Skarpie Estate was thus an attempt to reconcile tradition and innovation. In this way it can be interpreted as a return to the original principles of neoclassical urbanism and at the same time a promotion of contemporaneous architecture. It thus evidences the influence Polish postmodernist urbanism drew from socialist realism.

Loegler's scheme gained recognition in an architectural competition organised by the Kraków chapter of the architects' association SARP in 1985 on behalf of Budostal housing association (figure 1). Situated immediately east of Plac Centralny, Na Skarpie was the last portion in the centre of Nowa Huta that by the 1980s was still unbuilt, and a harmonic integration of the new buildings was considered essential. At the time all over Europe the negative image of Stalinist architecture and urbanism was being revised, whilst in conjunction neo-classical Nowa Huta was increasingly positively reviewed. Among the jury members were also Stanisław Juchnowicz (born 1923) and Janusz Ingarden (1923-2005), co-authors of the original 1950 plan. Likewise, the competition guidelines mandated a certain alignment with the original principles for infrastructural reasons, for example to take advantage of existing pipes and sewers. ${ }^{62}$ The competition brief clearly called for representative qualities, stating that the complex should become a "spatial sign recognizable at an urban scale. ${ }^{\prime \prime 3}$ There is much to suggest that the references to Nowa Huta's socrealist design were one of the principal reasons for Loegler's proposal being awarded the first prize, even though his colourful design differed in many ways from the original buildings' contained neoclassicism.

These references are clearly visible in the 1985 master plan, which was mostly carried out. ${ }^{64}$ The trapezoid area is limited on the north by the boulevard Aleja Rewolucji Kubańskiej (now Aleja Jana Pawła II) and on the south by the name-giving escarpment that borders the wetland of the River Vistula. The connection to Plac Centralny on the northwest edge is accentuated through a diagonal street in northwest-southeast direction that provides a vista similar to those in the neo-classical Nowa Huta plan. On the east the area borders the modernist State Music School (begun 1959, Marek Jabłoński) and the Światowid Cinema (begun 1957, Andrzej Uniewski, now a local history museum), whose impressive neoclassical façade rhythm with quadrangular two-storey columns is somewhat repeated in the lower portion of Loegler's and his team's six-storey block (figure 24). References to postmodernist urbanism along the lines of Aldo Rossi or Rob Krier are visible, for example, in the interior squares and some buildings that correspond to a traditional block plan. At the same time there are also aspects of functionalist tower-inthe-park design, such as the car infrastructure and the integration of buildings and greenery.

[figure 24 near here]

Architecturally the project is dominated by an elongated six-storey block aligned in eastwest direction parallel to the boulevard (figure 14). With a horizontally and vertically structured façade, accentuated entrances and groundfloor commercial spaces, the block was intended to be the physical boundary of the boulevard's side strip. The block has several extensions to the south that give it a comb-shaped plan. The teeth of the comb, composed of five-storey blocks, form three small squares that are connected by the diagonal northwest-southeast street. The southern end of the squares is made up of several four-storey blocks separating the scheme from the Vistula wetland. Some of the comb's teeth reach across the escarpment, ending in four-storey buildings that rest on stilts (figure 25). 
[figure 25 near here]

Inherent in the master plan is the vision of a city centred on street and square, and a porous urban continuum as opposed to a functionalist separation into self-contained neighbourhoods. Over the course of the design process these principles were nonetheless blurred. The squares, against the original intention, were filled with parking cars that tended to block the carefully designed vistas. The gate-like openings in the six-storey block, which which were intended to connect boulevard and neighbourhood, were blocked off by a continuous two-storey commercial building on the boulevard's side strip. In contrast to the porous row of small pavilions foreseen in the master plan, the continuous structure obstructs the connection between boulevard and neighbourhood.

Postmodernist elements dominate façade and volumes of most buildings. There are representative multi-coloured plaster façades, French windows, and accentuated stairwells topped by triangular gables; there are glass bricks and other ornaments assembled in classical harmonies; and there is the principle of variation over the same aesthetic themes. There are also non-orthogonal flat plans with open kitchens and flexibly programmed rooms that nonetheless fit into the overall harmony of the buildings (figure 26).

[figure 26 near here]

The sophisticated forms reflect the changed situation in Poland's construction industry during the late 1980s. Given progressive market liberalization architects were no longer required to limit their design vocabulary to the one-size-fits-all products of the "house factories." Moreover, Na Skarpie was to a large extent built from prefabricated materials, but smaller and more flexible ones than the panels of Radogoszcz-East. ${ }^{65}$ The prestige of the project facilitated the investment of more resources on the part of the state authorities. Lastly, the architect was institutionally largely independent and was internationally well connected.

As in Radogoszcz-East and Różany Potok there is no evidence that the stylistic innovations of the project were obstructed by the Party leaders. On the contrary, Loegler remembered that many high-ranking Party officials were genuinely supportive of postmodernist design as a means of diversifying and "humanizing" the increasingly unloved block architecture. These included Kraków Politechnika professor, Zbigniew Zuziak, who from 1984-92 was Kraków's Chief Architect. ${ }^{66}$ Objections, if any, were only voiced with regard to the scarcity of non-standard materials under the slacking socialist economy.

At the time Loegler had been exposed to the work of international postmodernists. He was one of the few Polish architects who took part in the West Berlin IBA. Along with his team partners Wojciech Dobrzański, Jacek Czekaj and several others he was invited in 1986 to take part in a workshop, which eventually led to the design of the multifamily building on Dessauer Straße 34-35 in Berlin (built 1991-93). This building, like many IBA projects, interpreted historical typologies for contemporary uses as dense, inner-city residences. The façade design shows a sophisticated play with a vertical and horizontal grid of brickface applications that overlays a white plastered wall with asymmetrically assorted, historically inspired window openings. The two and three-room flats have balconies to the inner portion of the block, thus reproducing the traditional hierarchy of public street and semi-public courtyards that was also influential in the Na Skarpie development.

The impact from the West Berlin discourse on the Na Skarpie Estate is also evident in Loegler's project for a Willa Miejska ("Urban Villa"). ${ }^{67}$ (figure 27) Already the project name recalls the IBA, where the term was popularized for freestanding, medium-rise, multifamily residences surrounded by public space and modelled after pre-modernist precedents. Loegler's Urban Villa, a four-storey building on an L-shaped plan, was eventually built on the southeast corner of the development (address: Osiedle Centrum E no. 3). It features a façade symmetrically structured by bay windows and balconies on both sides of a conspicuous glazed stairwell with a blue steel frame.

[figure 27 near here]

The Na Skarpie scheme also shows a certain influence of structuralist thinking along the lines of that which played out in Radogoszcz-East and Różany Potok. This is reflected in a 1985 discussion published in Architektura, in which Loegler points out the differences of his and his "Kraków School's" approach to that of his Warsaw colleagues. Warsaw architect 
Jerzy Szczepanik-Dzikowski, one of the designers of the previously mentioned WarsawUrsynów district, interpreted architecture as a social process to which the architect should be subservient. Loegler, in contrast, saw it as the architect's task to listen to inhabitants' impulses and criticism, but eventually set the parameters of urban design, including axes and volumes, based on historical developments and the respect for long-term directions. ${ }^{68}$

Absorbing all these influences, $\mathrm{Na}$ Skarpie came to be architecturally the most sophisticated of the three "postmodernist mass housing complexes" discussed in this article. Its unusual forms resulted from particular conditions: a prestigious project in a comparatively resourceful city, built at a time when the system of industrialized construction was slowly giving way to customization and individualized design, and an architect with international experience and a comparatively high degree of creative independence. At all these levels the Na Skarpie scheme exemplifies the leeway under the declining socialist regime.

\section{Conclusion}

The short-lived encounter between postmodernism and socialist mass housing yielded a number of noteworthy projects that were reflective of the conditions in late socialist Poland and the limited possibilities of modifying industrialised construction and functionalist urbanism. At the time, designers all over the Eastern bloc aimed at modification of standardized blocks and design elements in order to take into account cultural or climatic differences. Examples range from the flamboyantly ornamented blocks in Soviet Central Asia, to the historicising panel blocks in Hungary or the prefab tenements in the German Democratic Republic. The Polish case was unusual only insofar as it developed against the background of a progressive decline of the centralised construction industry, as well as the gradual establishment of market elements and localised decision-making. These promoted the use of non-standardized materials for design proposals oriented towards volumetric design and historical typologies.

The relationship between architects' ideas and socialist realities is particularly obvious in the Radogoszcz-East case, but it is likely that it was a similar feature in the Rózany Potok and $\mathrm{Na}$ Skarpie case studies too. Much suggests that all three projects were subject to similar tensions in the decision-making process. There was an inflexible system of stateoperated construction firms, there were public housing associations with a certain degree of leeway, and there were headstrong architects with good negotiation skills and a comparatively high degree of creative freedom. The studio system within the stateoperated construction firms in Poland afforded architects the opportunity for comparatively independent design activities. Professional organisations and forums for exhibition and exchange were less restricted than in other socialist countries, and, from as early as the 1970s, architects rarely faced political pressure or censorship of their ideas. All this led to a thriving professional discourse, of which the three cases are material examples.

Poland's "postmodernist mass housing blocks" took up influences not only from the obvious postmodernist themes of typology and historical quotations such as those exemplified in the works of Aldo Rossi or Rob Krier. To a similar extent they were generated by late modernist currents, in particular structuralism as promoted by Aldo van Eyck or Piet Blom, as well as the domestic discourse on open form connected with Oskar Hansen and his supporters.

The gap between theory and practice was particularly wide given the hardships architects had to face. In conjunction with the chronic shortage of labour and materials and the obstacles posed by inefficient bureaucracy, the boundaries of architectural innovation in mass housing design were set by the inflexibility of comprehensive planning and vertically integrated construction firms. Unlike their colleagues designing for the fledgling private market, mass housing architects had to deal with the declining centralised planning organs. In all the presented cases these constraints led to significant modification of the original ideas; in the case of Różany Potok, where large portions were only completed after the end of the socialist regime, the scheme was eventually realised as a hybrid neighbourhood reflecting both socialist and post-socialist conditions.

In this context it was to a large extent personal commitment that generated innovative architecture and planning. The lead architects for the projects in this article, Jakub Wujek, Marian Fikus, Jerzy Gurawski, and Romuald Loegler owed their success not only their 
creative energy but just as much to their persistence, negotiation skills, and ability for improvisation and ad-hoc management. Postmodernist mass housing blocks stand witness to the leeway that existed under a seemingly inflexible authoritarian regime, as well as to the individuals who managed to use it to their advantage. In this sense they were a reflection of the social and political conditions in the last decade of socialist Poland.

${ }^{1}$ Postmodernism in this context is very broadly defined, following, for example Heinrich Klotz, The History of Postmodern Architecture (Cambridge, MA: MIT Press, 1988) or Nan Ellin, Postmodern Urbanism (New York: Princeton Architectural Press, 1996).

2 See for example Andrzej Basista, Betonowe Dziedzictwo - Architektura w Polsce czasów komunizmu (Warsaw: Wydawnictwo Naukowe PWN, 2001); Lidia Klein and Alicja Gzowska, eds., Postmodernizm polski - architektura i urbanistyka (Warsaw: Wydawnictwo 40000 Malarzy, 2013); Błażej Ciarkowski, Odcienie szarości. Architekci i polityka w PRL-u (Łódź: Politechnika Łódzka, 2017); Grzegorz Piątek, "Bardzo długa transformacja" Autoportret 54 n. 3 (2016), 36-43; or the special number "Architektura Postmodernizmu" of Autoportret 63 n. 4 (2018) with contributions from Aleksandra Stępień-Dąbrowska, Piotr Winskowski, Łukasz Wojciechowski and others. See also Łukasz Stanek, Postmodernizm jest prawie w porządku: polska architektura po socjalistycznej globalizacji (Warsaw: Bęc Zmiana, 2012), 59-72 [in Polish and English]; Anna Cymer, Architektura w Polsce 1945-1989 (Warsaw: Centrum Architektury and Narodowy Instytut Architektury i Urbanistyki, 2018); or Lidia Klein and Alicja Gzowska, "Late Socialist Postmodernism and Socialist Realism in Polish Architecture" in Vladimir Kulić, ed., Second World Postmodernisms (London: Bloomsbury, 2018)

3 For two of the few studies on postmodern panel buildings see Błażej Ciarkowski, "Postmodernizm a prefabrykacja- wielka płyta w zabytkowym centrum Łodzi," in Lidia Klein, ed., Postmodernizm Polski. Architektura i urbanistyka. Antologia tekstow (Warsaw: Wydawnictwo 40000 Malarzy, 2013), 375-98 and the insightful book by Błażej Ciarkowski, Miastoprojektanci. Łódzcy architekci w czasach PRL-u (Łódź: Księży Młyn, 2018), particularly the chapter on Pracownia no. 3, pp. 127-52. On Na Skarpie see also Dorota Jędruch, "Osiedle Centrum E - czyli piknik na wisząca skarpa" in Jarosław Klaś, ed., Nowa Huta - architektoniczny portret miasta drugiej połowy XX wieku (Kraków: Ośrodek Kultury im. Cypriana Norwida, 2018), 96-103.

${ }^{4}$ Andrzej Basista, Betonowe Dziedzictwo - Architektura w Polsce czasów komunizmu (Warsaw: Wydawnictwo Naukowe PWN, 2001), 78-9; see also Edmund Sergot, "'Fabryki domów' a architektura mieszkaniowa," Architektura n. 2 (1985), 34-6.

${ }^{5}$ Dariusz Grala, Reformy gospodarcze w PRL (1982-1989). Próba uratowania socjalizmu (Warsaw: Trio, 2005), in particular 125-183. See also Brian Porter-Szücs, Poland in the Modern World (Chichester: Wiley, 2014), 300-20.

${ }^{6}$ For a discussion of the Party position in the 1980s see Błażej Ciarkowski, Odcienie szarości. Architekci i polityka w PRL-u (Łódź: Politechnika Łódzka, 2017), 83 and 127-39.

7 Edmund Sergot, "'Fabryki domów' a architektura mieszkaniowa," Architektura n. 2 (1985), 36.

${ }^{8}$ Grundsätze für die sozialistische Entwicklung von Städtebau und Architektur in der DDR Minutes of the Politburo meeting on 18 May 1982, final version, Federal Archive Berlin DY 30/J IV 2/2 1947: 238; see also Florian Urban, The New Tenement (Abingdon: Routledge, 2018), 76-78.

9 Philipp Meuser and Dimitrij Zadorin, Towards a Typology of Mass Housing Prefabrication in the USSR 1955-1991 (Berlin: Dom Publishers, 2015).

${ }^{10}$ Wiol [author abbreviation] "Pogrzeb prof. Wujka, projektanta wielu łódzkich budynków" Gazeta Wyborcza [Łódź edition] 21 February 2014.

${ }^{11}$ See the complaints in Zdzisław Lipski and Jakub Wujek, "Doświadczeia z projektowania i realizacji dużych zespołow mieszkaniowych na terenie Łodzi," Architektura n. 429 January/February 1986, 25.

12 Andrzej Owczarek, conversation with the author, Łódź, 14 August 2018.

13 On control and reorganisation of construction companies in socialist Poland, particularly cooperative construction, see Andrzej Basista, Betonowe Dziedzictwo - Architektura w Polsce czasów komunizmu (Warsaw: Wydawnictwo Naukowe PWN, 2001), 16-17.

${ }^{14}$ Archiwum Państwowe w Łodzi, collection Urząd Dzielnicowy Łódź-Bałuty, Dokumentacja Architektoniczno-Budowlana 1987-88, call number 6344, p. 2.

${ }^{15}$ Błażej Ciarkowski, Odcienie szarości. Architekci i polityka w PRL-u (Łódź: Politechnika Łódzka, 2017), 83-87. 
${ }^{16}$ Materials of the plenary meeting of the Łódź Committee of the PZPR on 23 February 1980, Archiwum Państwowe $w$ Łodzi, collection KŁ PZPR, call number 158, p. 13. See also other minutes, call numbers 159-64.

${ }_{17}$ Andrzej Owczarek, conversation with the author, Łódź, 13 September 2018. See also Anna Kulik, Józef Niewiadomski - wywiad rzeka z prezydentem Łodzi w latach 1978-85 (Łódź: Księży Młyn, 2015).

${ }_{18}$ Andrzej Owczarek, "Jakub Wujek" in Elżbieta Fuchs, ed., Jakub Wujek (Łódź: Miejska Galeria Sztuki, 2016) [exhibition catalogue], 6-15.

19 Elżbieta Fuchs, ed., Jakub Wujek (Łódź: Miejska Galeria Sztuki, 2016) [exhibition catalogue], 105-8.

${ }^{20}$ See for example Krystyna Greger, Zdzisław Lipski, Andrzej Owczarek, Jerzy Sadowki, Jakub Wujek, Projekty 1965-72 (Łódź- Miastoprojekt, 1972) [exhibition catalogue].

${ }_{21}$ Zdzisław Lipski and Jakub Wujek, "Doświadczenia z projektowania i realizacji dużych zespołow mieszkaniowych na terenie Łodzi," Architektura n. 429 (January/February 1986), 35; Andrzej Owczarek, conversation with the author, Łódź, 14 August 2018.

22 Jakub Wujek, "Moderne und Postmoderne im polnischen Städtebau" Bauwelt (West Berlin) 80 n. 43 (10 November 1989), 1034-5.

${ }_{23}$ Florian Urban, The New Tenement (Abingdon: Routledge, 2018), 197-256.

24 For an analysis of structuralist influences on this development see also Błażej Ciarkowski, Miastoprojektanci. Łódzcy architekci w czasach PRL-u (Łódź: Księży Młyn, 2018), 136-43 and Andrzej Owczarek, "Jakub Wujek" in Elżbieta Fuchs, ed., Jakub Wujek (Łódź: Miejska Galeria Sztuki, 2016) [exhibition catalogue], 12-13.

${ }_{25}$ Krystyna Greger, Zdzisław Lipski, Andrzej Owczarek, Jerzy Sadowki, Jakub Wujek, Projekty 1965-72 (Łódź: Miastoprojekt Łódź, 1972) [exhibition catalogue], 12.

26 Miastoprojekt Łódź [Andrzej Owczarek and others], Katalog otwarty domów rekreacyjnych dla Wojewódzdwa Piotrokowskiego - zasady wariantowania i wymienności rozwiązań przestrzenno-technicznych (Łódź: Miastoprojekt Łódź, 1979), [exhibition catalog], p. 1.0 .

27 On the international repercussion of structuralist housing schemes see for example C. de Wit, "Geordende Kasbah-stedebouwkundig beeld van een menswaardige habitat in de toekomst?" Bouw 1963, 1474. See also Arnulf Lüchinger, "Strukturalismus-eine neue Strömung in der Architektur" Bauen und Wohnen (Zurich) 30 n. 1 (January 1976), 5-9.

${ }_{28}$ Andrzej Owczarek, conversation with the author, Łódź, 13 September 2018.

${ }^{29}$ Ibid.; Krystyna Greger, Zdzisław Lipski, Andrzej Owczarek, Jerzy Sadowski, Jakub Wujek, Projekty 1965-72 (Łódź: Miastoprojekt Łódź, 1972).

30 Jakub Wujek, "Moderne und Postmoderne im polnischen Städtebau" Bauwelt 80 n. 43 (10 November 1989, 1034-5.

31 Zdzisław Lipski and Jakub Wujek, "Doświadczenia z projektowania i realizacji dużych zespołow mieszkaniowych na terenie Łodzi" Architektura n. 429 January/February 1986, 32.

${ }^{32}$ Ibid., 28-30.

33 Ibid., 22.

${ }^{34}$ Andrzej Owczarek, conversation with the author, Łódź, 13 September 2018.

35 Ibid.

${ }^{36}$ Ibid.

37 Jakub Wujek, "Rozmowa" in Lidia Klein and Alicja Gzowska Postmodernizm polski architektura $i$ urbanistyka. Rozmowy $z$ architektami (Warsaw: Wydawnictwo 40000 Malarzy, 2013), 114-16.

38 Zdzisław Lipski and Jakub Wujek, "Doświadczenia z projektowania i realizacji dużych zespołow mieszkaniowych na terenie Łodzi" Architektura n. 429 (January/February 1986), 34.

39 Ibid. 34-5. In the publication the plans seem to be mismatched to the year dates, as the year dates are out of order, and in addition do not correspond to the construction phases visible in the plans and the adjacent texts. My interpretation is based on a corrected attribution, that is, I re-ordered the plans and re-attributed the year dates, and matched them with the different construction phases.

${ }^{40}$ Zdzisław Lipski and Jakub Wujek, "Doświadczenia z projektowania i realizacji dużych zespołow mieszkaniowych na terenie Łodzi" Architektura n. 429 January/February 1986, 38-40.

${ }^{41}$ Jakub Wujek, "Rozmowa" in Klein, Lidia and Alicja Gzowska Postmodernizm polski architektura $i$ urbanistyka. Rozmowy $z$ architektami (Warsaw: Wydawnictwo 40000 Malarzy, 2013), 116. 
42 Jakub Wujek, "Pięćdziesiąt lat póżniej" Architektura 32 n. 3 (May 1980), 22.

${ }^{43}$ Jakub Wujek, Mity i utopie architektury XX wieku (Warsaw: Arkady, 1986), in particular pp7-8. The book was first published in chapters in Architektura n. 1-4 (1983).

${ }^{44}$ Jakub Wujek, "Neoromantyczne Fascynacje w Architekturze" in Architektura Powszednia, Architektura Uboga - Materialy z VII Ogólnopolskiej Kowersatorium Polskiej Architektury Wspólczenej 4-5 November 1986 (Kraków: Polska Akademia Nauk, 1988), 5.

${ }^{45}$ Marian Fikus and Jerzy Gurawski, Projekt nowego uniwersytetu im. Adama Mickiewicza w Poznaniu (Poznan: Wydawnictwo Naukowe Uniwersytetu im. Adama Mickiewicza, 1978); Marian Fikus and Jerzy Gurawski, "Przestrzenno-funkcjonalny element integrujacy" Architektura n. 12 (1976) 32-6.

${ }^{46}$ Ibid.

${ }^{47}$ Marian Fikus, conversation with the author, Poznań, 24 September 2018.

48 Ibid.

49 Oskar Hansen, "Forma otwarta w architekturze. Sztuka wielkiej liczby" [1960], reprinted in Marcin Lachowski, Magdalena Linkowska, Zbigniew Sobczuk, eds., Wobec Formy Otwartej Oskara Hansena. Idea - utopia - reinterpretacja (Lublin, 2009), 14; Oskar Hansen, Ku formie otwartej [edited by Jola Gola] (Warsaw: Fundacja Galeria Foksal, 2005).

${ }^{50}$ Marian Fikus and Jerzy Gurawski, "Przestrzenno-funkcjonalny element integrujący" Architektura n. 12 (1976), 34.

51 Marian Fikus, Przestrzeń w zapisach architekta (Poznań: Wydział Architektury i Planowania Przestrzennego Politechniki Poznańskiej, 1999), 128-34.

52 Jerzy Gurawski, "Rozmowa" in Lidia Klein and Alicja Gzowska Postmodernizm polski architektura $i$ urbanistyka. Rozmowy z architektami (Warsaw: Wydawnictwo 40000 Malarzy, 2013), 254-60; Marian Fikus, conversation with the author, Poznań, 24 September 2018.

53 Marian Fikus, conversation with the author, Poznań, 24 September 2018.

${ }^{54}$ Dariusz Grala, Reformy gospodarcze w PRL (1982-1989). Próba uratowania socjalizmu (Warsaw: Trio, 2005), 125-183.

${ }_{55}$ Romuald Loegler, conversation with the author, Kraków, 1 September 2018.

56 Ibid.; see also Maciej Miłobędzki, "Warszawscy pejsażiści, Krakówscy geometrzy" Autoportret (Kraków) 16 n. 2 (2017), 89.

${ }^{57}$ Romuald Loegler, conversation with the author, Kraków, 1 September 2018.

${ }^{58}$ Krystyna Styrna-Bartkowicz, Loegler. Synopsis (Kraków: Wydawnictwo RAM, 2015), 8689 and 206-7.

59 Łukasz Stanek, Postmodernizm jest prawie w porządku: polska architektura po socjalistycznej globalizacji (Warsaw: Bęc Zmiana, 2012); Łukasz Stanek, "Miastoprojekt goes abroad: the transfer of architectural labour from socialist Poland to Iraq (19581989)," Journal of Architecture 17 n. 3 (2012), 361-86.

60 Romuald Loegler, 2011, quoted in kukasz Stanek, Postmodernizm jest prawie $w$ porządku: polska architektura po socjalistycznej globalizacji (Warsaw: Bęc Zmiana, 2012), 41.

${ }^{61}$ Romuald Loegler, "Na Skarpie - Zespół Mieszkaniowy" 1983-85 in Archiwum Urzędu Miasta Krakówa, Binder Budownictwa i Architektury BA, p. 7.

${ }_{62}$ Romuald Loegler, conversation with the author, Kraków, 1 September 2018.

63 "Konkurs SARP na rozwiazanie zespołu mieszkalnego i koncepcji programowoprzestrzennej 'Skarpy' w Nowej Hucie" , Architektura n. 1 (1986), 53.

${ }^{64}$ Romuald Loegler, "Na Skarpie - Zespół Mieszkaniowy" 1983-85 in Archiwum Urzędu Miasta Krakówa, Binder Budownictwa i Architektury BA.

${ }_{66}^{65}$ Romuald Loegler, conversation with the author, Kraków, 1 September 2018.

${ }^{66}$ Ibid.

${ }^{67}$ Romuald Loegler, 1989, plans "Na Skarpie - Willa Miejska," dated 1989, Archiwum Urzędu Miasta Krakówa, Binder Budownictwa i Architektury BA.

68 Romuald Loegler and Jerzy Szczepanik-Dzikowski "Miasto czy Osiedle?" [conversation with Jeremi Królikowski], Architektura n. 4 (1984), 57-9. For similar ideas see also Romuald Loegler, "Nowy klasycyzm czy geometryczny romantyzm" Architektura 4-5 (1986), 65-6. 


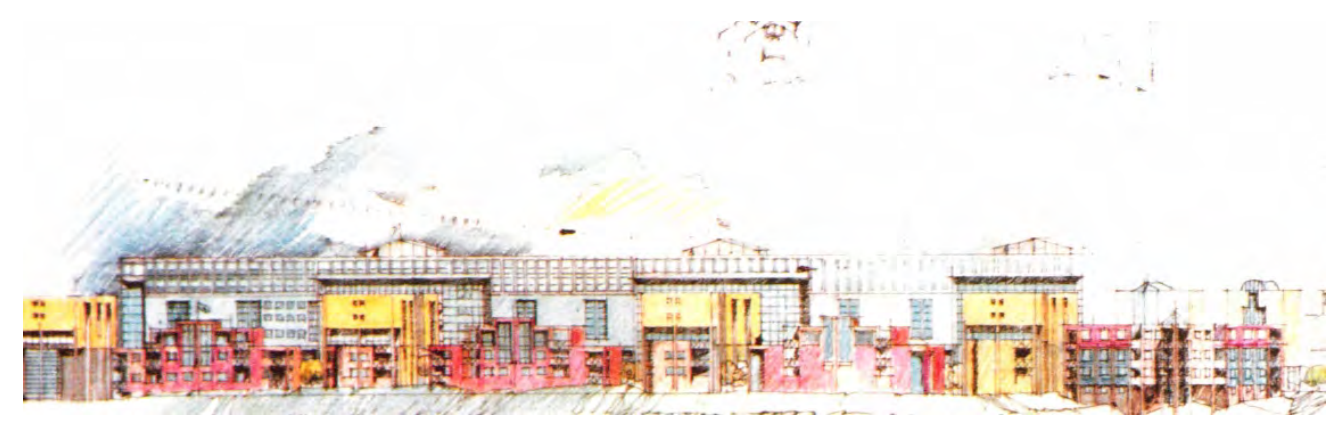

Figure 1: Romuald Loegler, Wojciech Dobrzański, Michał Szymanowski, Na Skarpie Estate in Kraków-Nowa Huta, first-prize-winning proposal, reprinted in Architektura 40 n. 1 (January 1986), p. 2.

$284 \times 86 \mathrm{~mm}(300 \times 300 \mathrm{DPI})$ 


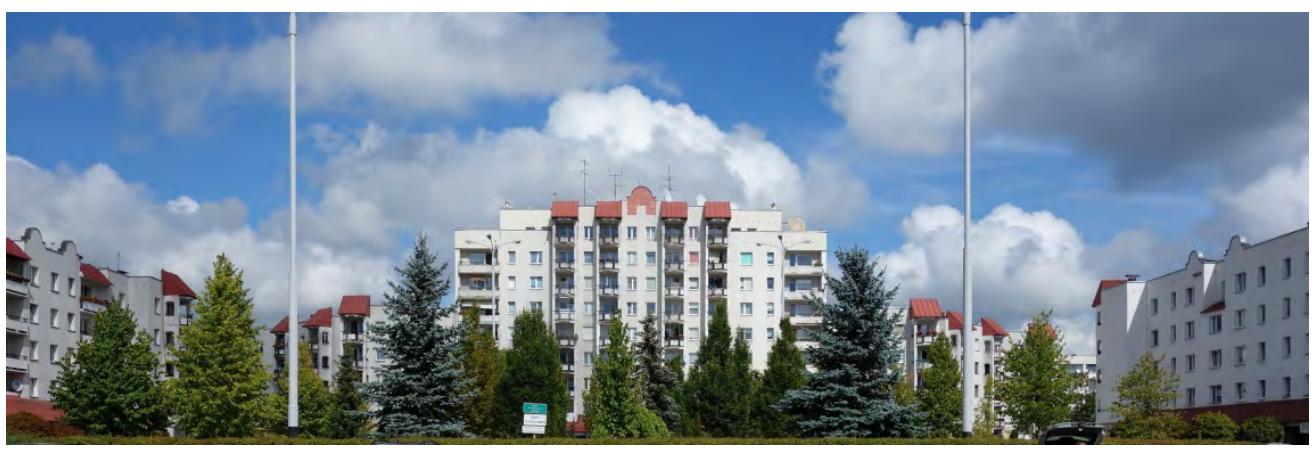

Figure 2: Plac Słoneczny ("Sunny Square") in the Radogoszcz-East estate in Łódź (1979-1989, Jakub Wujek, Zdzisław Lipski, Andrzej Owczarek) (author, 2018).

$198 \times 65 \mathrm{~mm}(300 \times 300$ DPI $)$ 


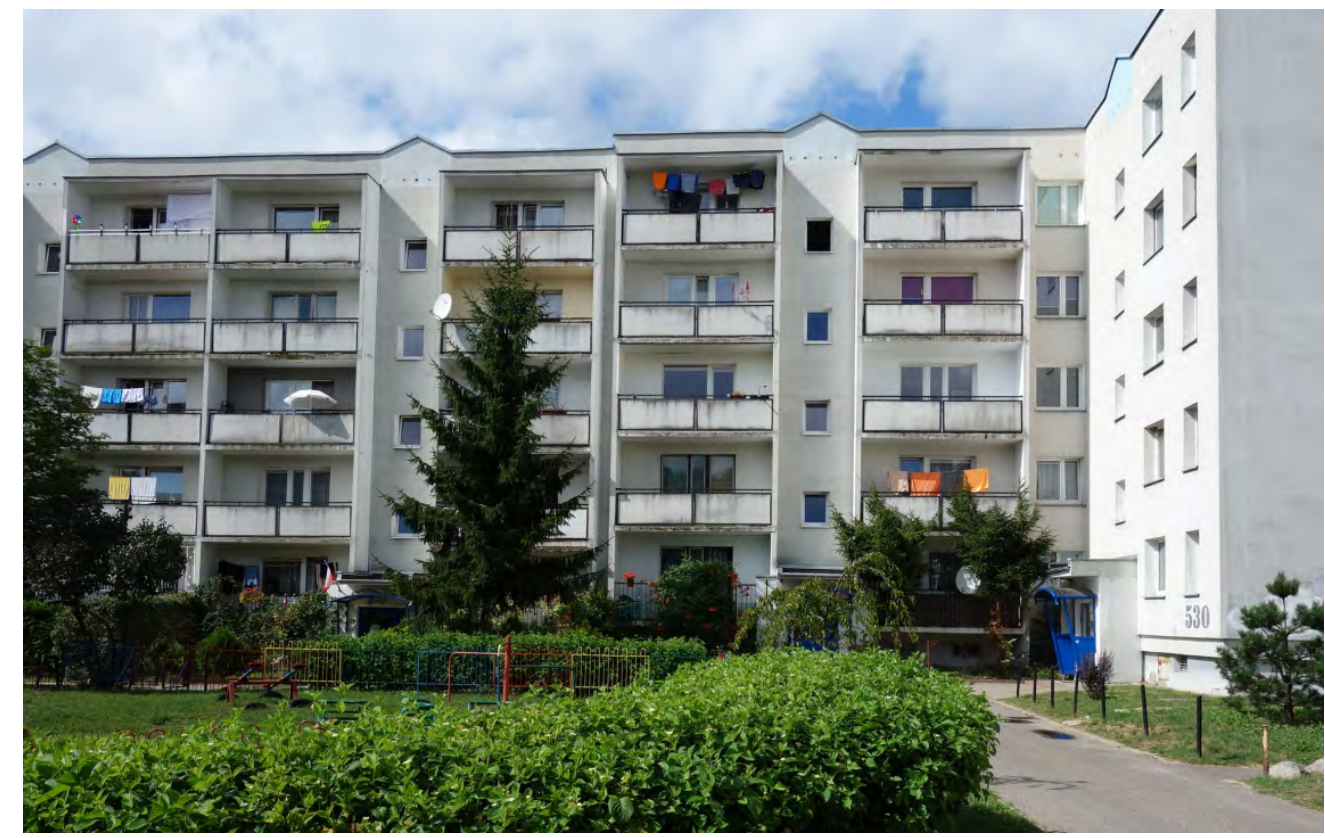

Figure 3: Radogoszcz-East, courtyard view of the building on Pstragowa 25, built 1985, looking northeast. The buildings were executed in the Szczecin construction system. The entrances are all from the courtyard side, requiring a walk from public spaces (streets) to semi-private spaces (courtyard) to private spaces (house) (author, 2018).

$191 \times 120 \mathrm{~mm}(300 \times 300 \mathrm{DPI})$ 


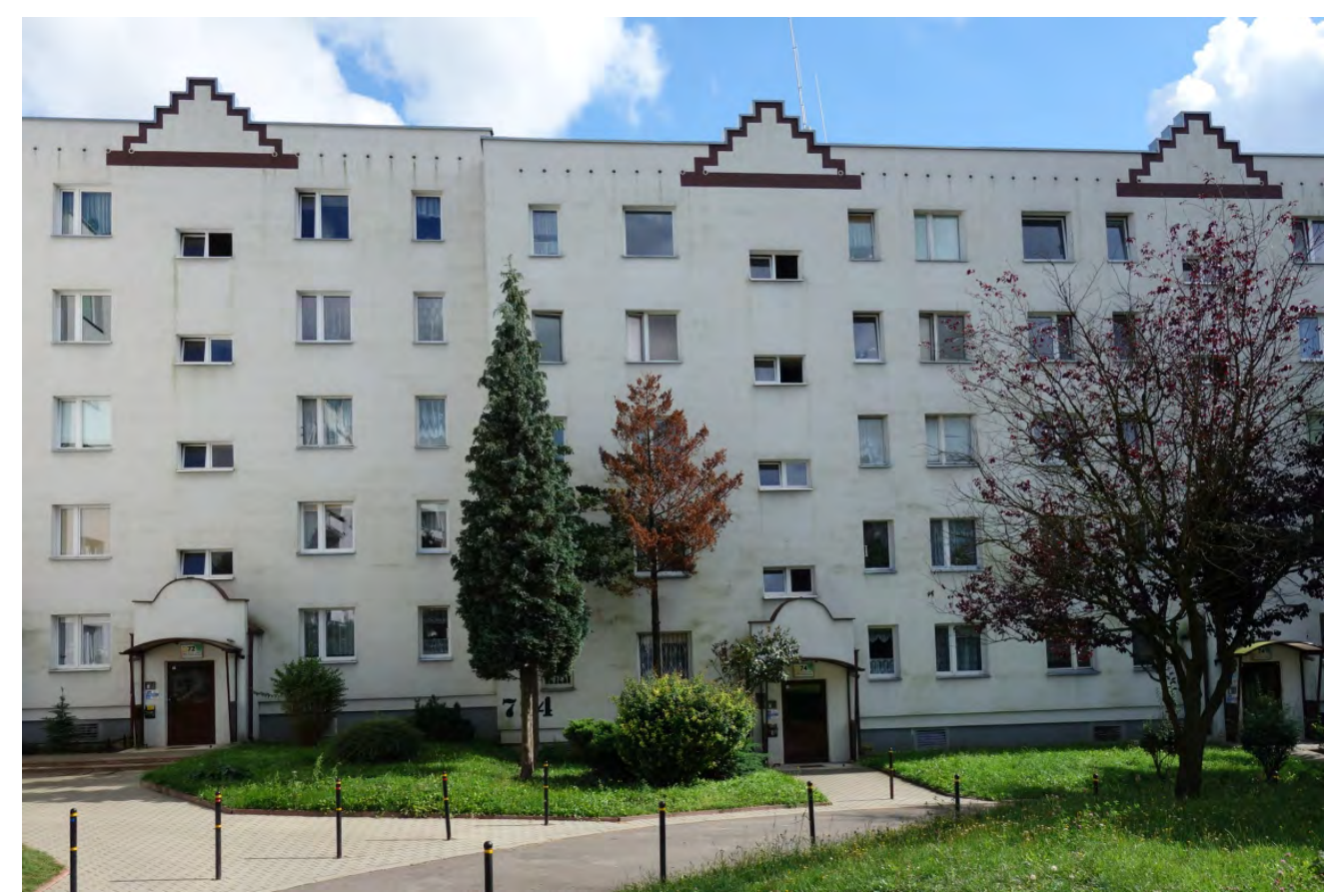

Figure 4: Radogoszcz-East, courtyard view of the building on Gustawa Herlinga-Grudzińskiego 7 (author, 2018).

$189 \times 127 \mathrm{~mm}(300 \times 300 \mathrm{DPI})$ 


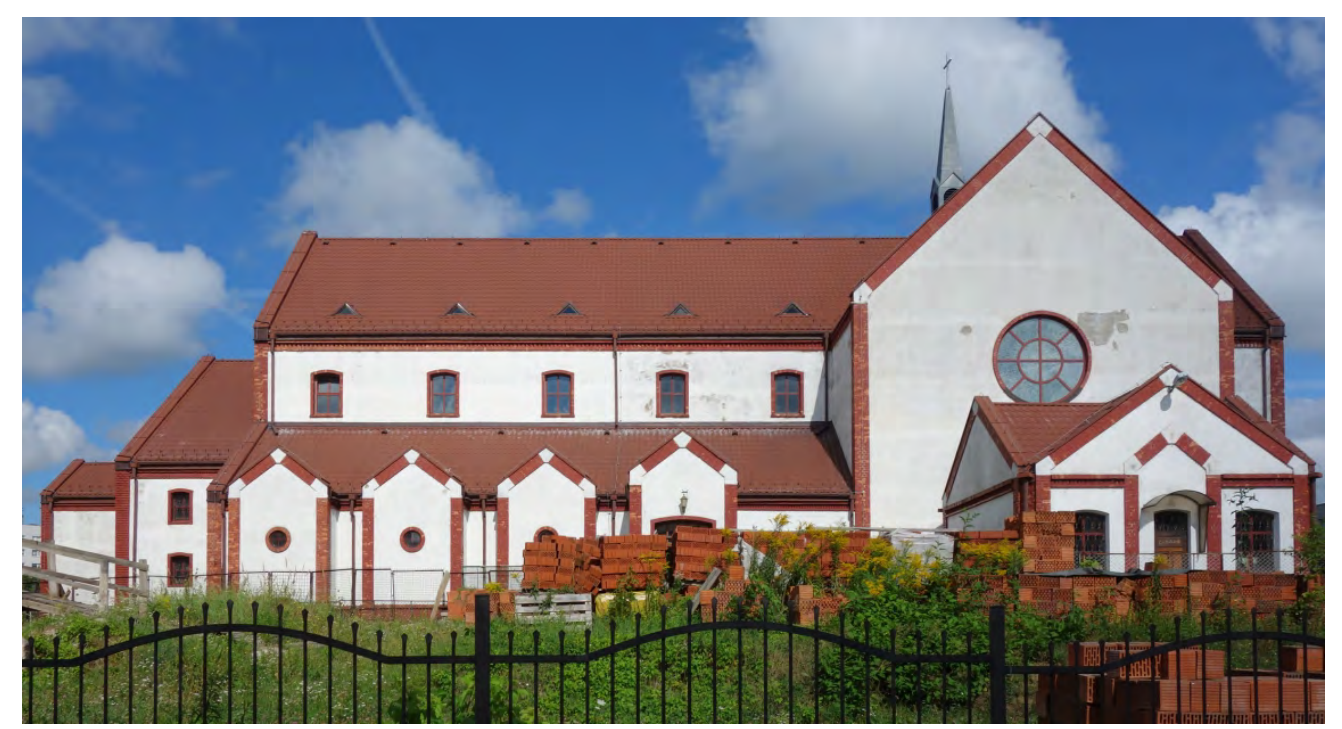

Figure 5: Radogoszcz-East, Holy Sacrament Church (1987-99, Jakub Wujek and Zdzisław Lipski) (author, 2018).

$183 \times 99 \mathrm{~mm}(300 \times 300 \mathrm{DPI})$ 


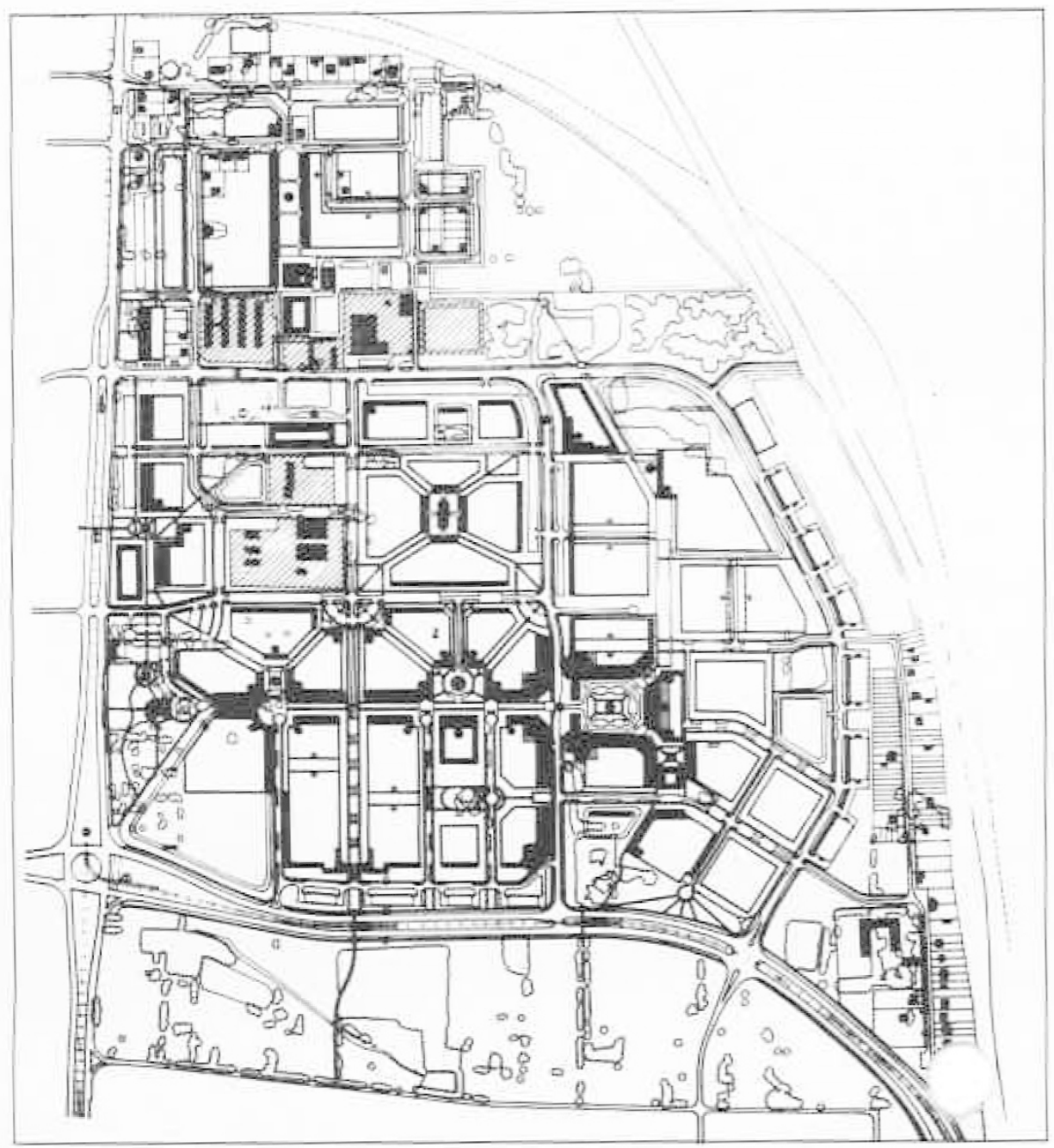

Figure 6: Radogoszcz-East, plan regulacyjny (master plan), 1978 (archive Andrzej Owczarek). $97 \times 103 \mathrm{~mm}(300 \times 300 \mathrm{DPI})$ 


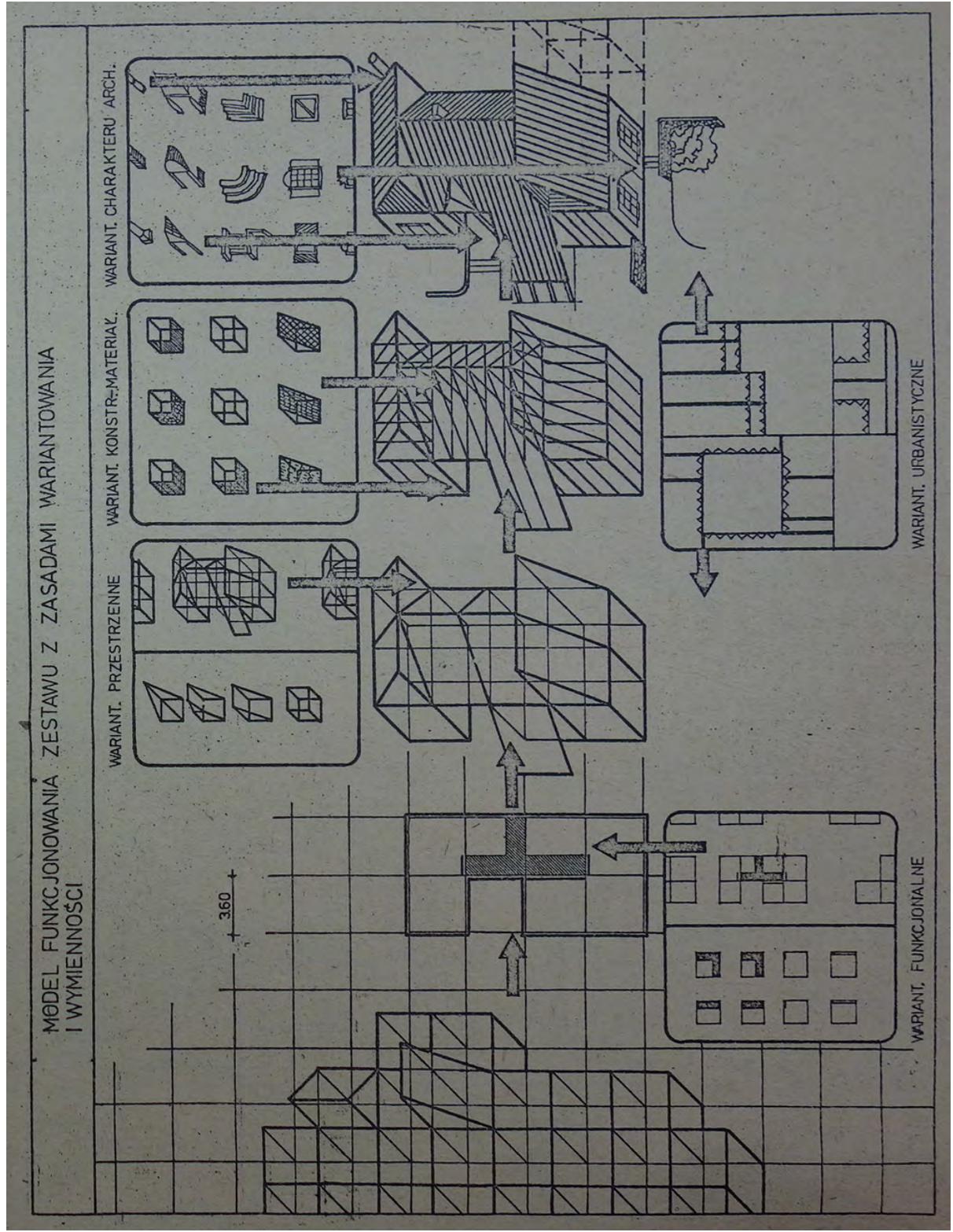

Figure 7: Radogoszcz-East, design for replaceability and combination, 1979. Miastoprojekt Łódź [Andrzej Owczarek and others], Katalog otwarty domów rekreacyjnych dla Wojewóddztowa Piotrokowskiego - zasady wariantowania i wymienności rozwiązań przestrzenno-technicznych (Łódź: Miastoprojekt Łódź, 1979) [exhibition catalog], p. 1.0

$85 \times 111 \mathrm{~mm}(300 \times 300 \mathrm{DPI})$ 

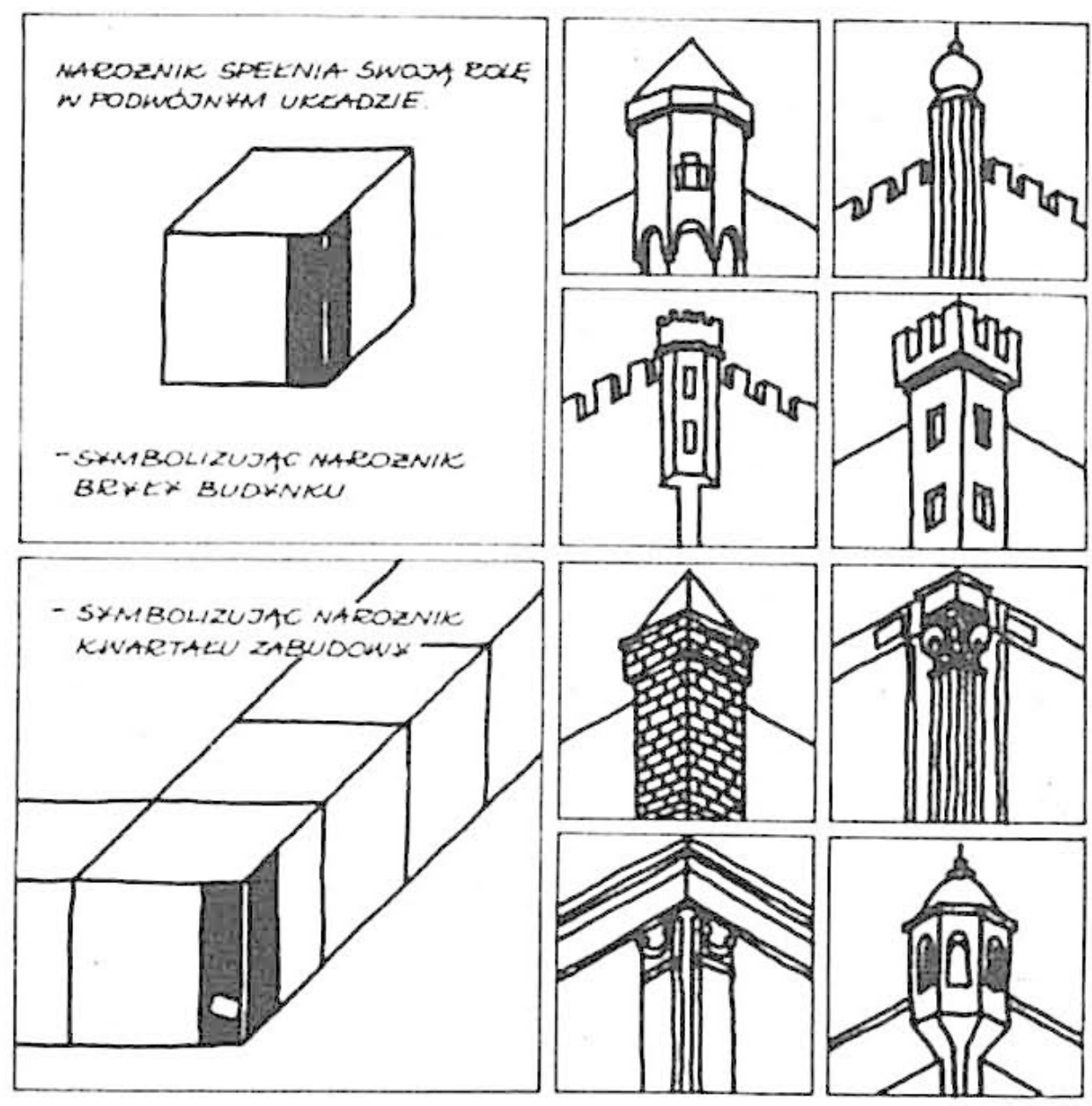

Figure 8: Radogoszcz-East, Precedents for corner solutions, in Zdzisław Lipski and Jakub Wujek, "Doświadczenia z projektowania i realizacji dużych zespołow mieszkaniowych na terenie Łodzi" Architektura n. 429 January/February 1986, 32.

$60 \times 60 \mathrm{~mm}(300 \times 300 \mathrm{DPI})$ 
Figure 9: Radogoszcz East, drawing of an ensemble between Romantyczna and Pstragowa, now Telmeny 10, $12,14,18$, c. 1985, published in Zdzisław Lipski, and Jakub Wujek, "Doświadczeia z projektowania i realizacji dużych zespołow mieszkaniowych na terenie Łodzi" Architektura n. 429 January/February 1986, 29.

\section{$55 \times 72 \mathrm{~mm}(300 \times 300 \mathrm{DPI})$}




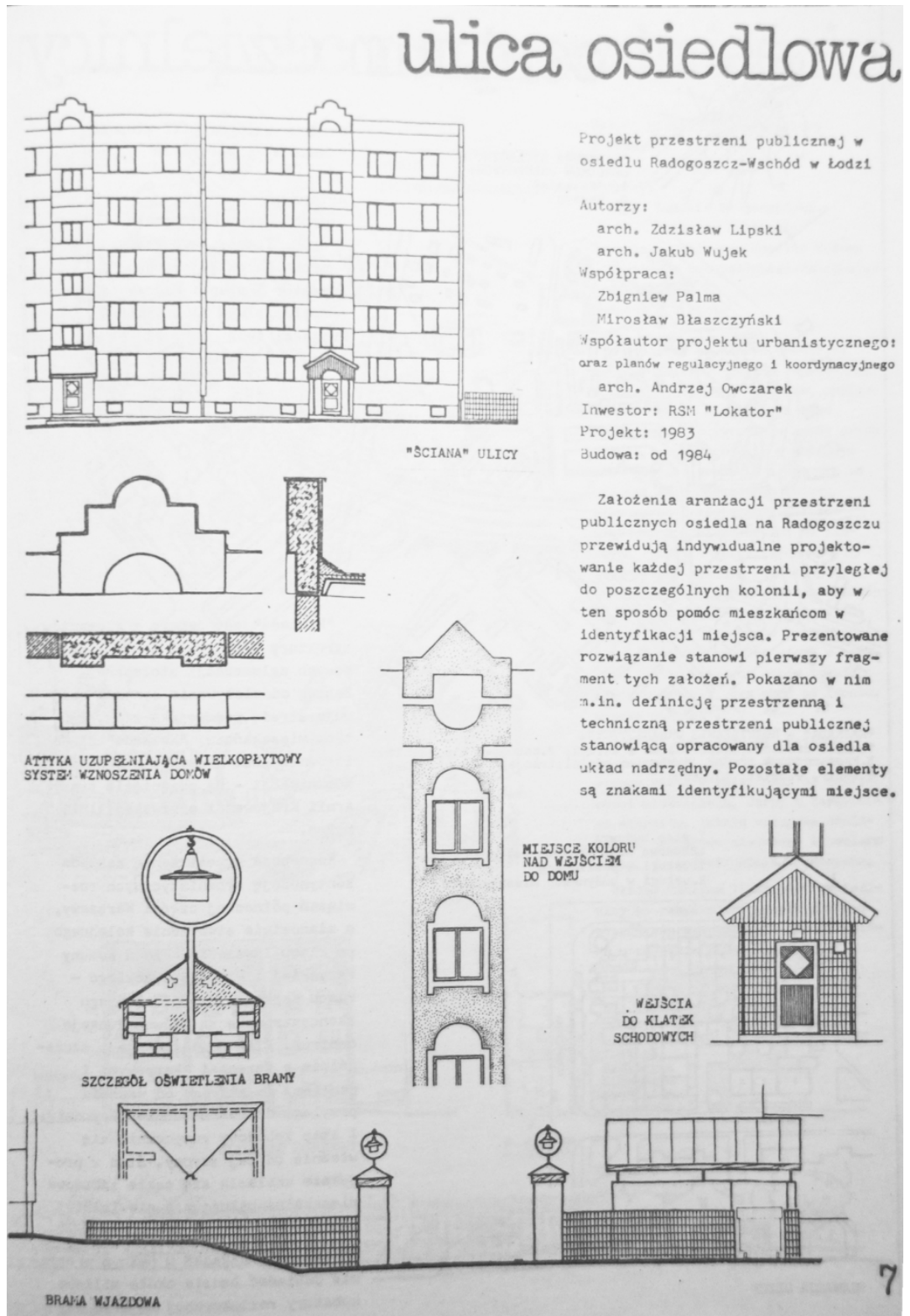

Figure 10: Radogoszcz-East, Elements to be added to the prefabricated panels, Zdzisław Lipski and Jakub Wujek, "Ulica osiedlowa w osiedlu Radogoszcz-Wschód w Łodzi" Komunikat SARP - Zeszyty Architektury Polskiej 1 n. 9-10 (1983), 6-7.

$128 \times 187 \mathrm{~mm}(300 \times 300 \mathrm{DPI})$ 


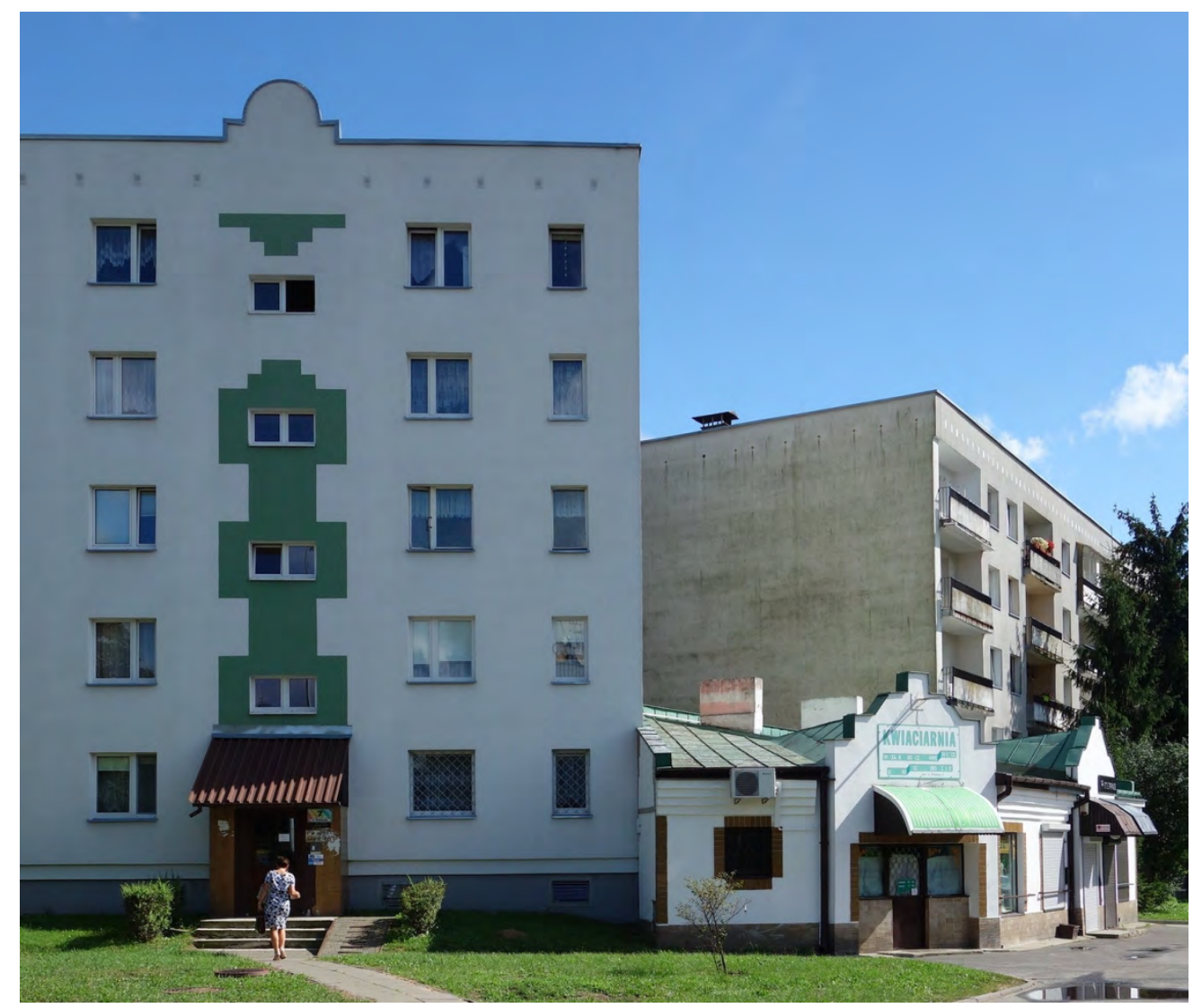

Figure 11: Radogoszcz-East, Blocks on Wiankowa 5, built 1983-84 in the W-70 system. In the spirit of Wujek and Lipski, who intended to merely give urban design guidelines taken up by other architects, the corner plot between the two buildings was later built up with flower shop using prefabricated parts to create a postmodern design (author, 2018).

$124 \times 105 \mathrm{~mm}(300 \times 300 \mathrm{DPI})$ 


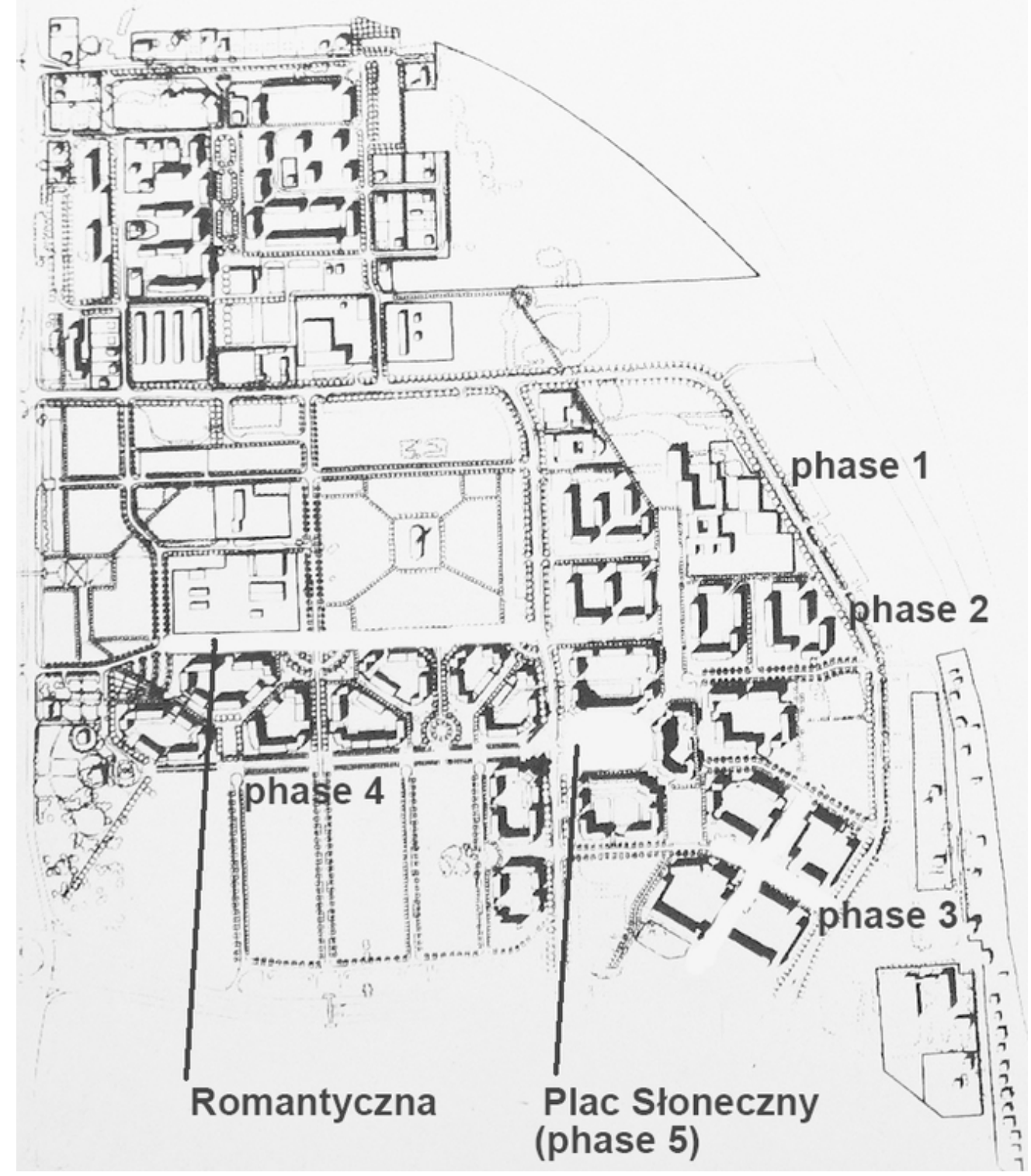

Figure 12: Radogoszcz East, buildings completed or under construction in 1985, Zdzisław Lipski and Jakub Wujek, "Doświadczeia z projektowania i realizacji dużych zespołow mieszkaniowych na terenie Łodzi" Architektura n. 429 January/February 1986, 35.

$56 \times 65 \mathrm{~mm}(300 \times 300 \mathrm{DPI})$ 


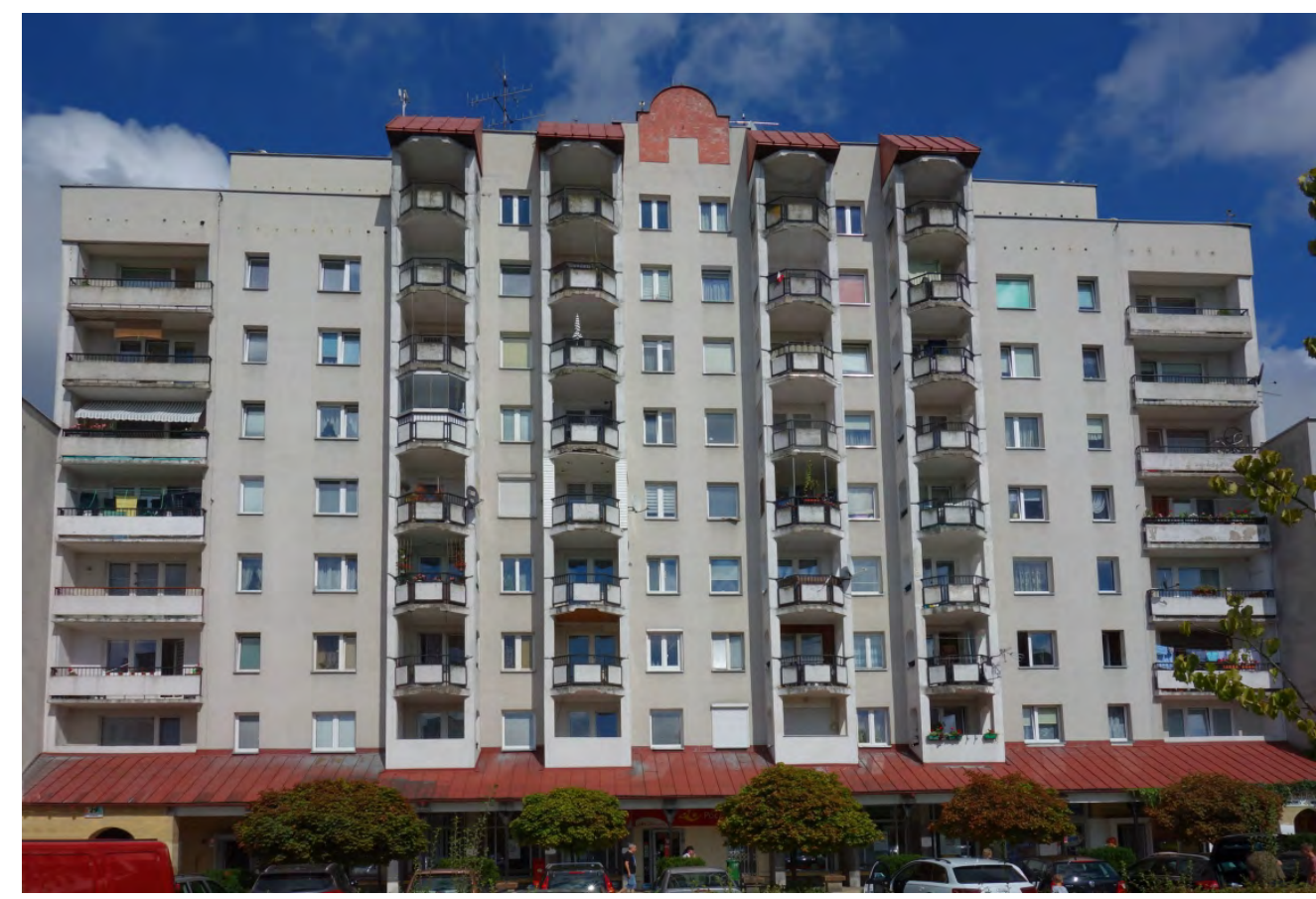

Figure 13: Radogoszcz-East, Plac Słoneczny (begun in 1985) with balconies and roof ornaments (author, 2018).

$204 \times 139 \mathrm{~mm}(300 \times 300 \mathrm{DPI})$ 


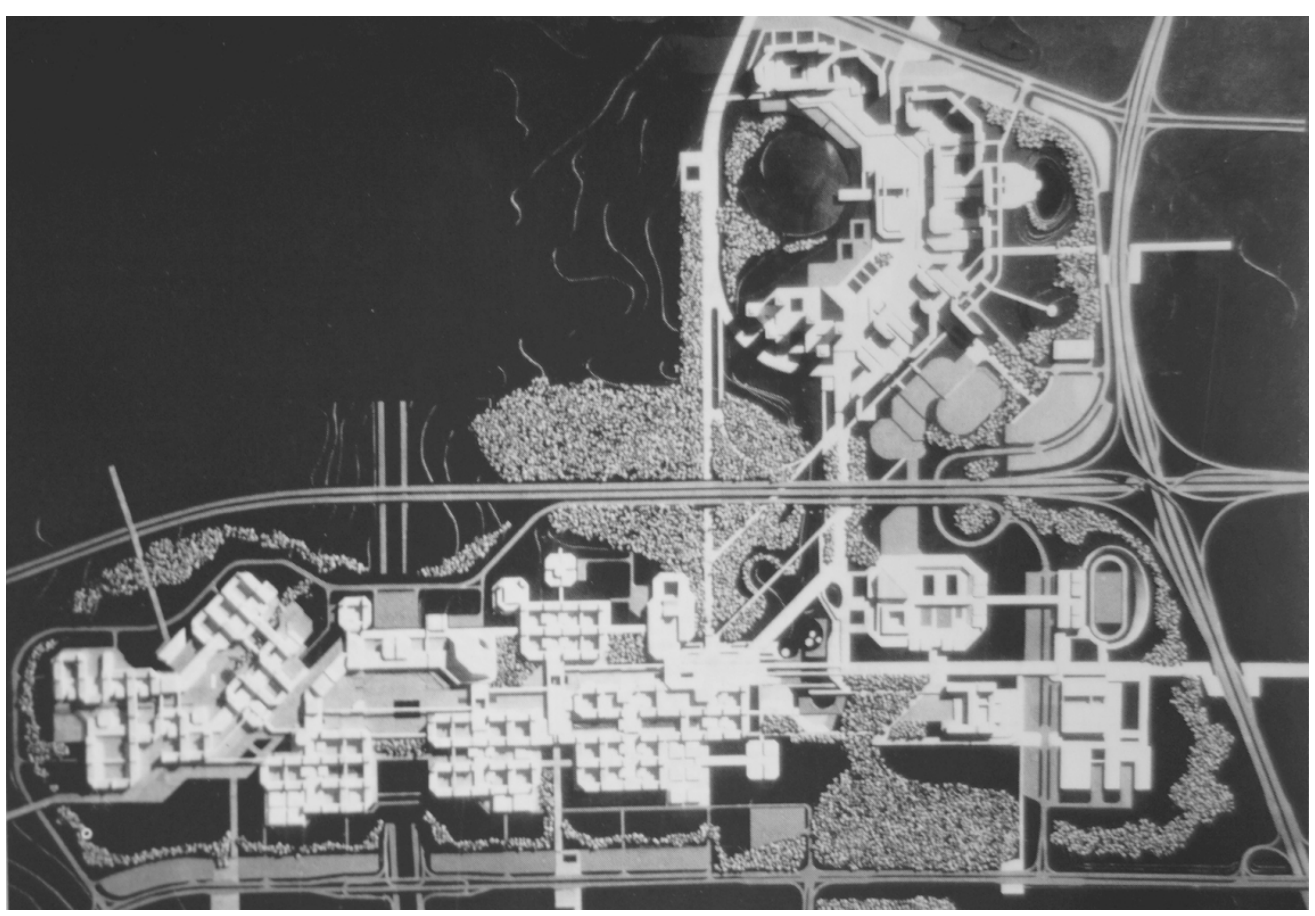

Figure 14: Marian Fikus/Jerzy Gurawski, competition entry for the University Campus in Poznań, 1974 (archive Marian Fikus).

$127 \times 87 \mathrm{~mm}(300 \times 300 \mathrm{DPI})$ 
Figure 15: Linear walkway in the Przyczółek Grochowski estate in Warsaw (1969-74, Oskar Hansen, Zofia Hansen) (author, 2018).

$198 \times 132 \mathrm{~mm}(300 \times 300 \mathrm{DPI})$

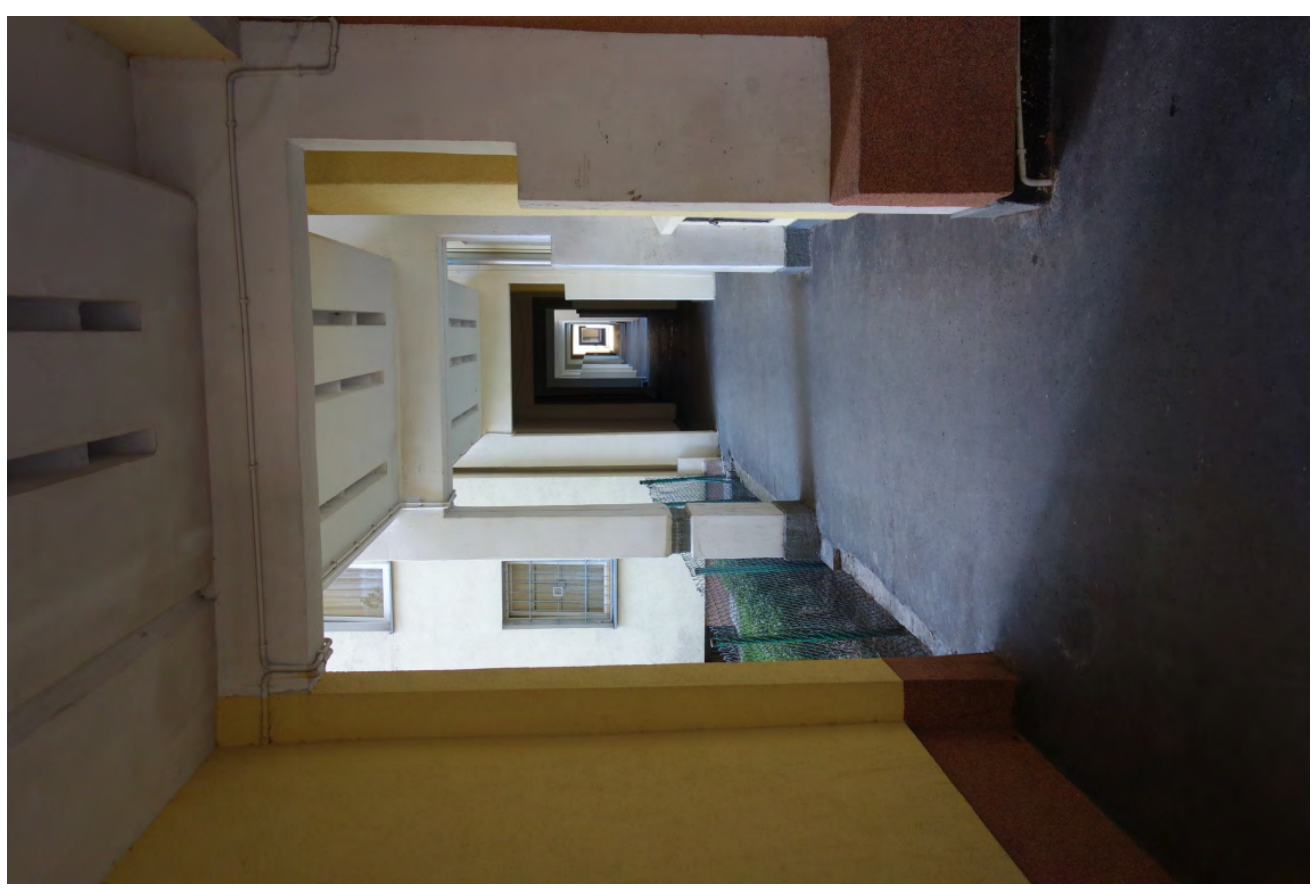




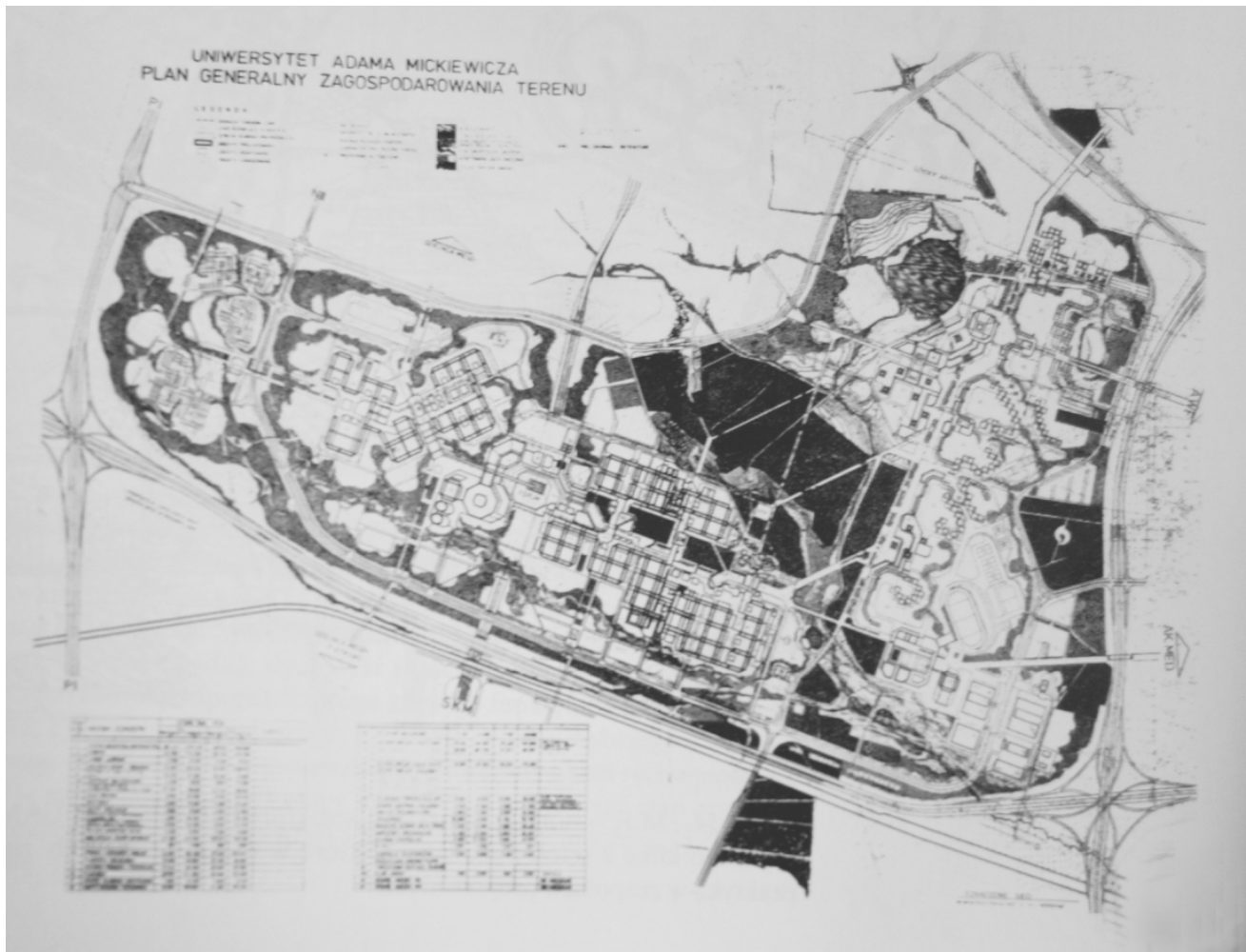

Figure 16: Marian Fikus/Jerzy Gurawski, revised second plan for the University Campus in Poznań, 1976 (archive Marian Fikus).

$142 \times 108 \mathrm{~mm}(300 \times 300 \mathrm{DPI})$ 


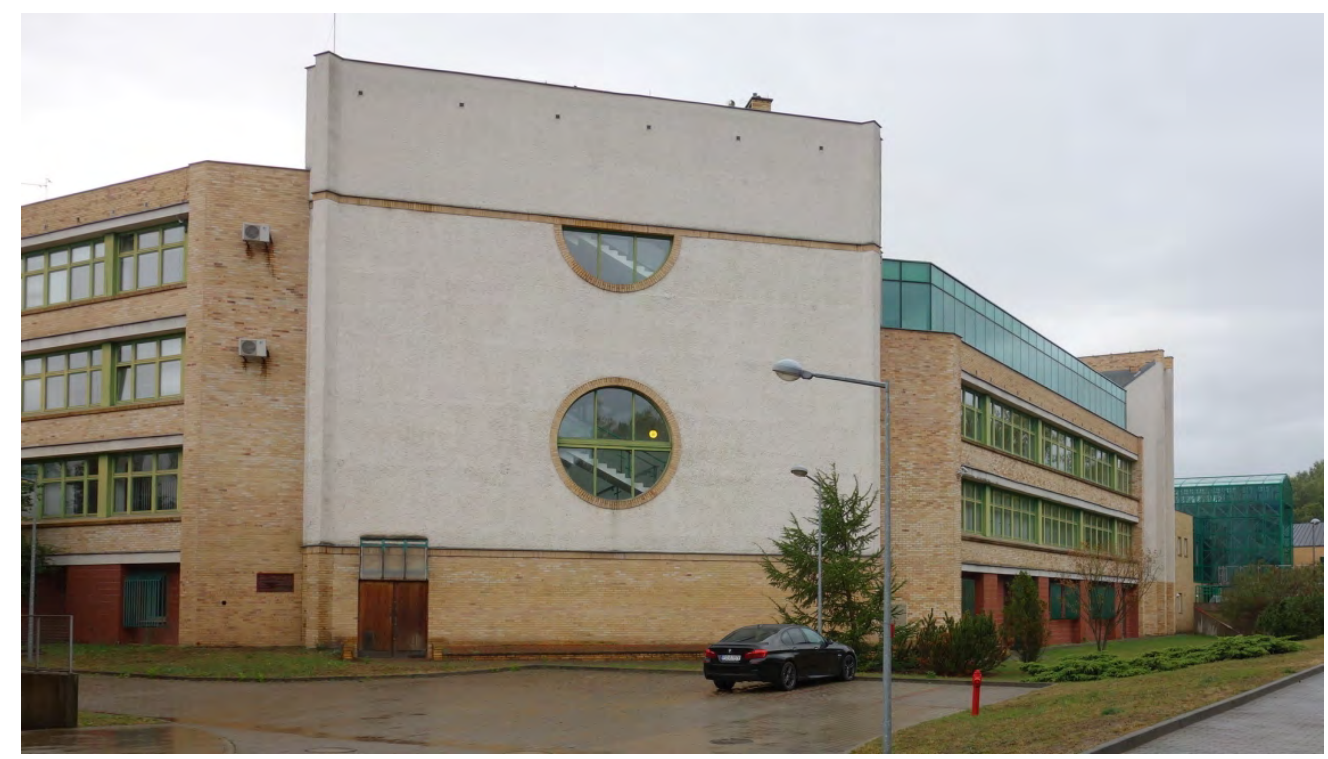

Figure 17: Department of Physics of the Adam Mickiewicz University in Poznań (1978-94, modified in 1999, Marian Fikus/Jerzy Gurawski) (author, 2018).

$$
160 \times 91 \mathrm{~mm}(300 \times 300 \mathrm{DPI})
$$




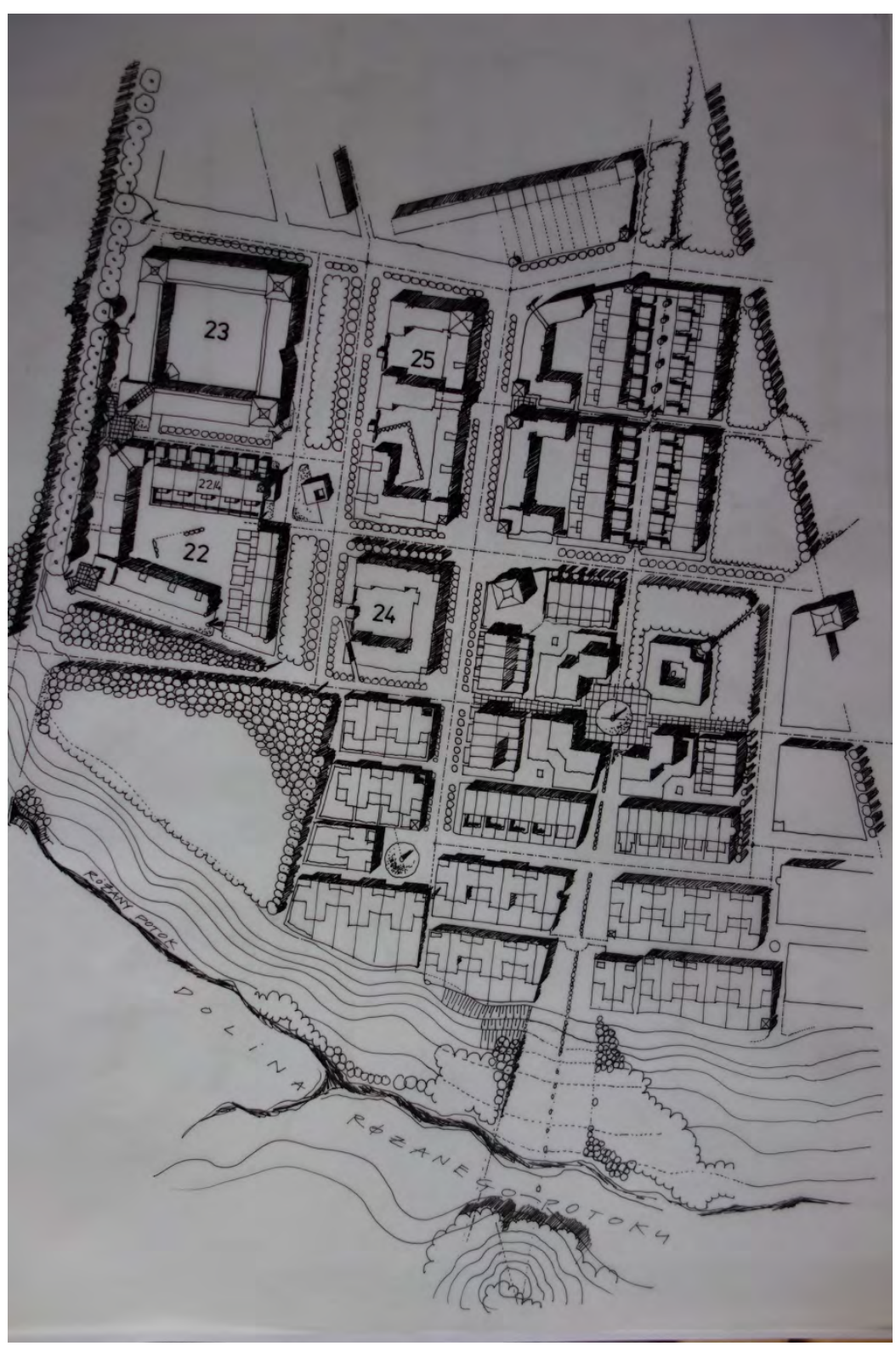

Figure 18: Różany Potok scheme, implementation plan (1984, Marian Fikus/Jerzy Gurawski) (archive Marian Fikus).

$132 \times 198 \mathrm{~mm}(300 \times 300 \mathrm{DPI})$ 


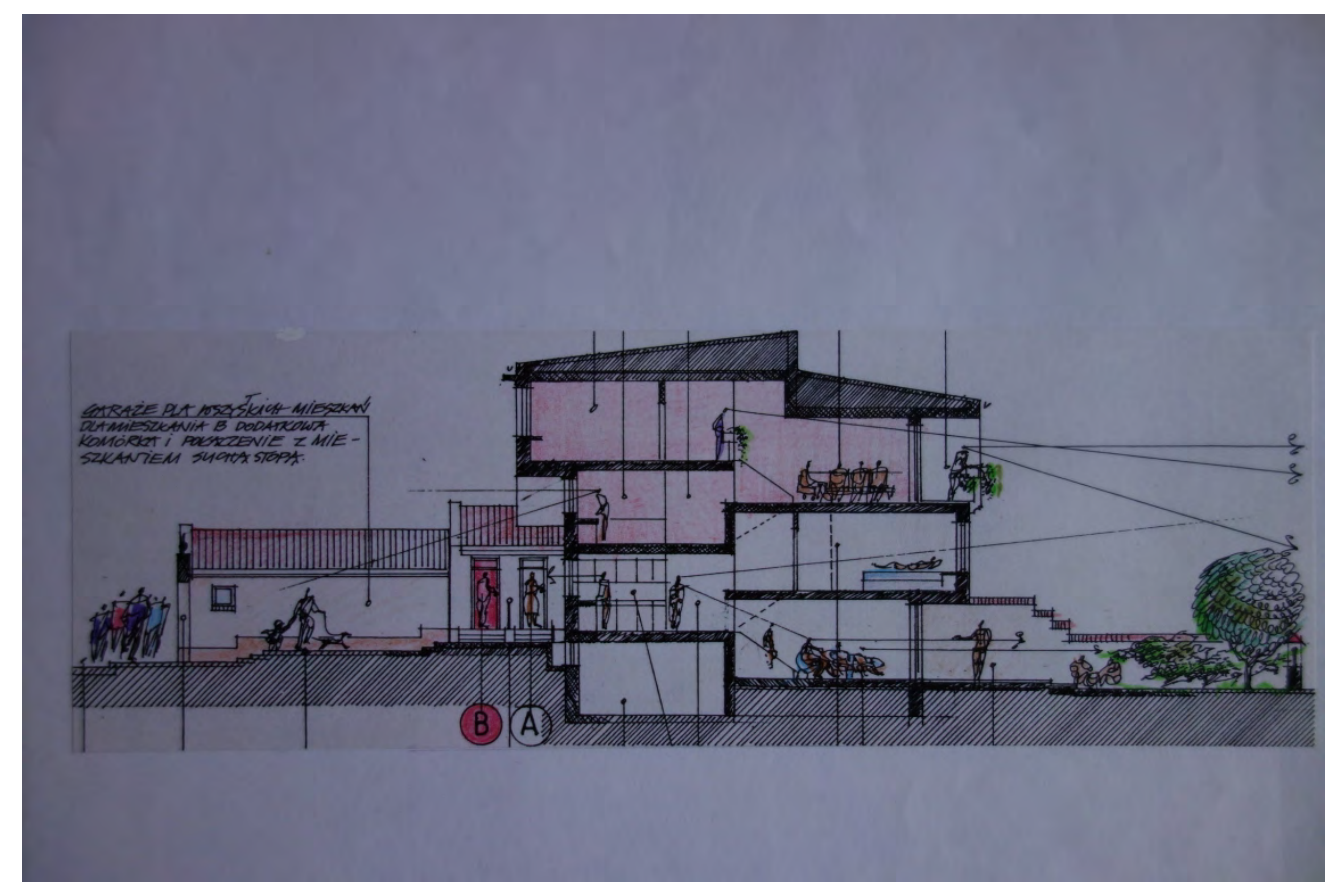

Figure 19: Różany Potok scheme, "double terraces", sectional drawing from 1988 (archive Marian Fikus). $198 \times 132 \mathrm{~mm}(300 \times 300 \mathrm{DPI})$ 


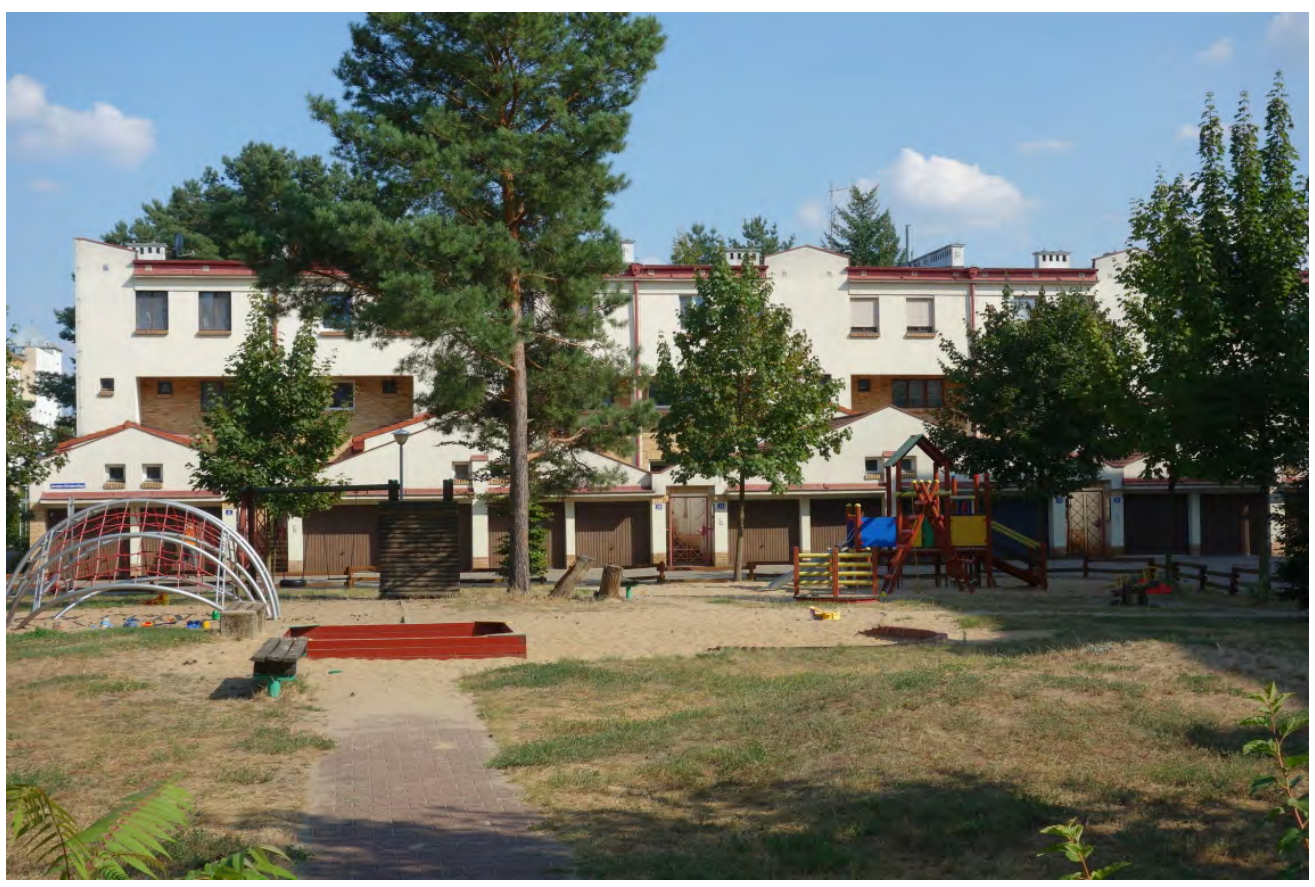

Figure 20: Różany Potok scheme, "double terraces" on Umultowska 100 D-G, designed by Studio Fikus, 1988-91 (author, 2018).

$198 \times 132 \mathrm{~mm}(300 \times 300 \mathrm{DPI})$ 


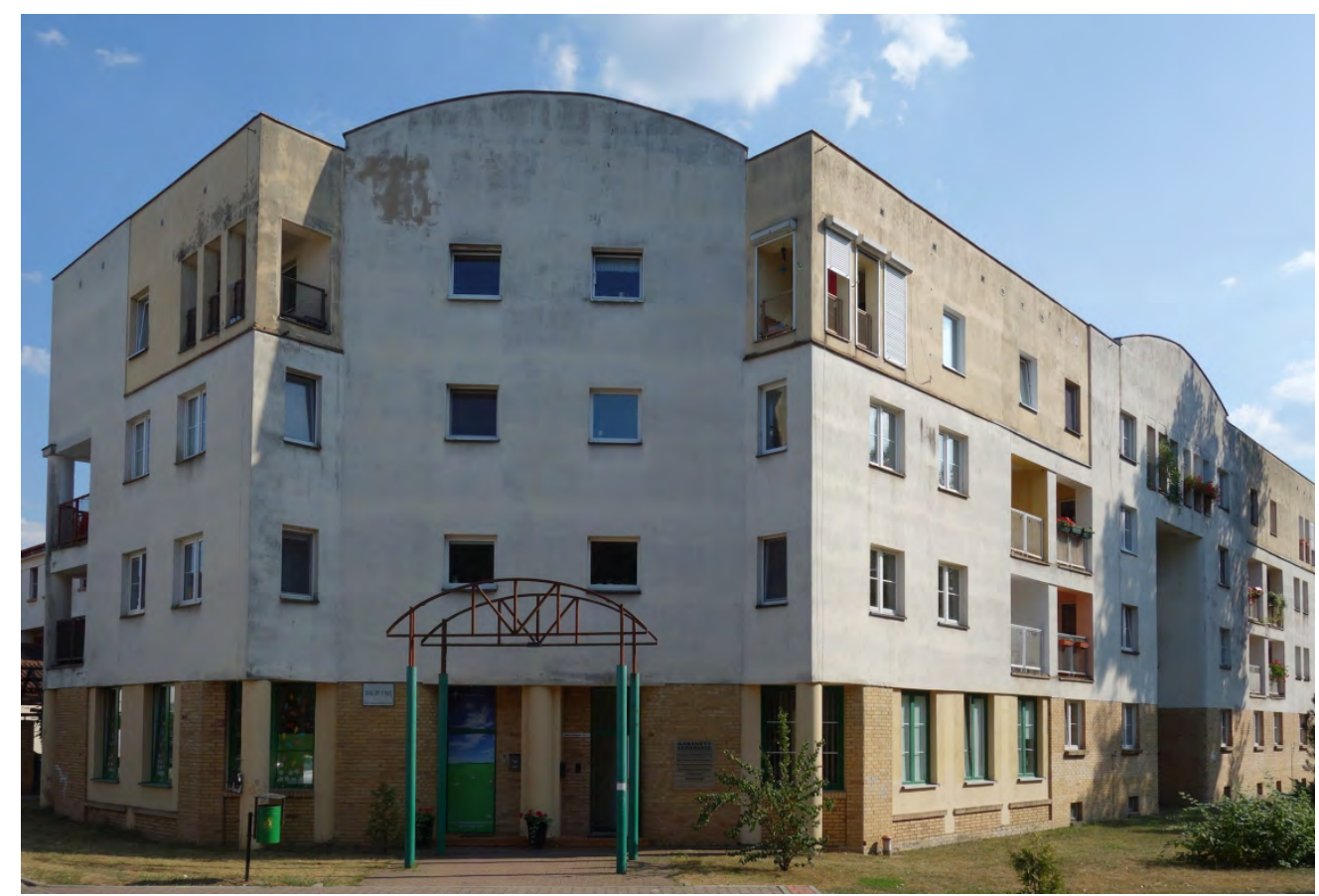

Figure 21: Różany Potok scheme, walk-ups on Umultowska 100-100A-C, designed by Studio Fikus, c. 1990 (author, 2018).

$181 \times 123 \mathrm{~mm}(300 \times 300 \mathrm{DPI})$ 


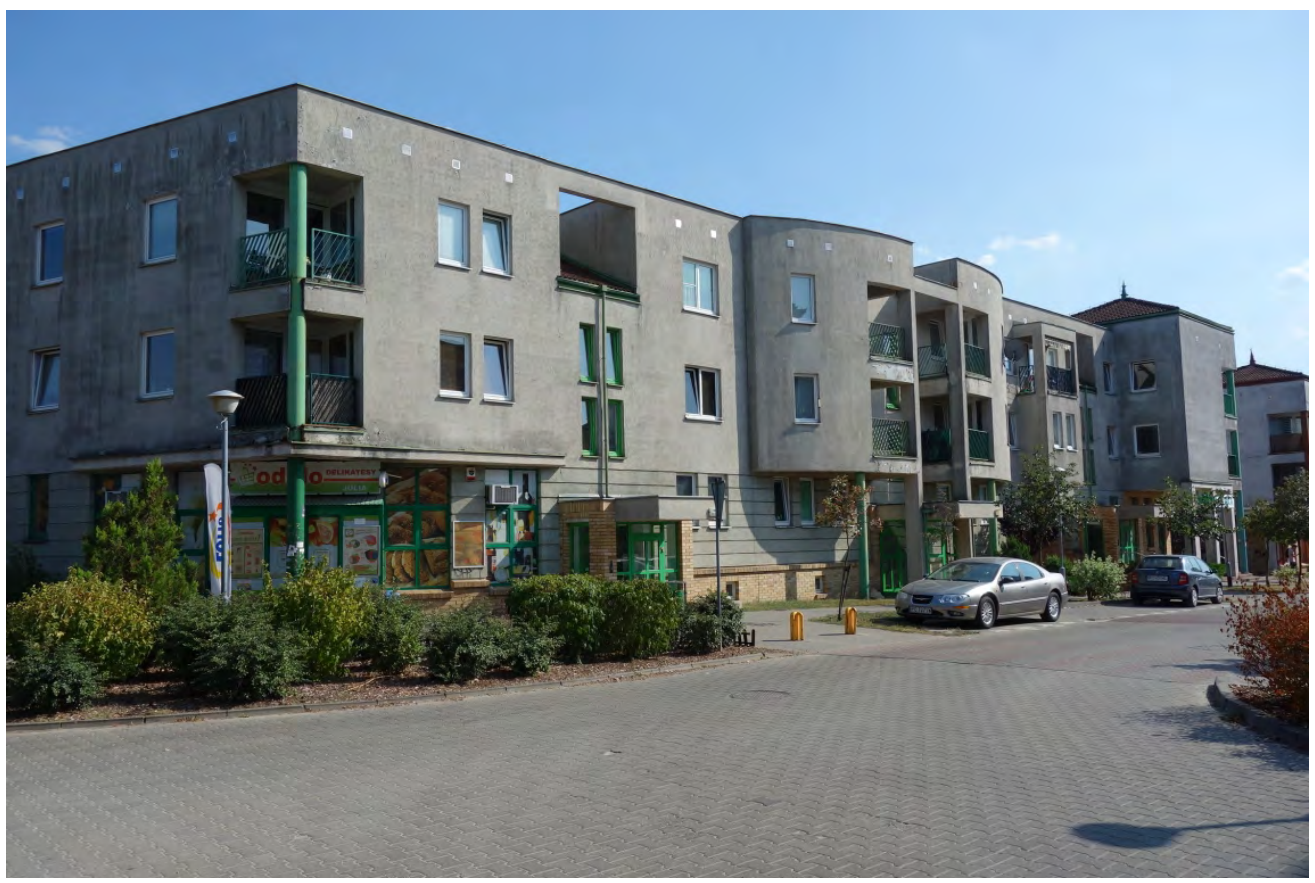

Figure 22: Różany Potok scheme, buildings on Romana Drewsa, looking southeast (author, 2018). $198 \times 132 \mathrm{~mm}(300 \times 300 \mathrm{DPI})$ 


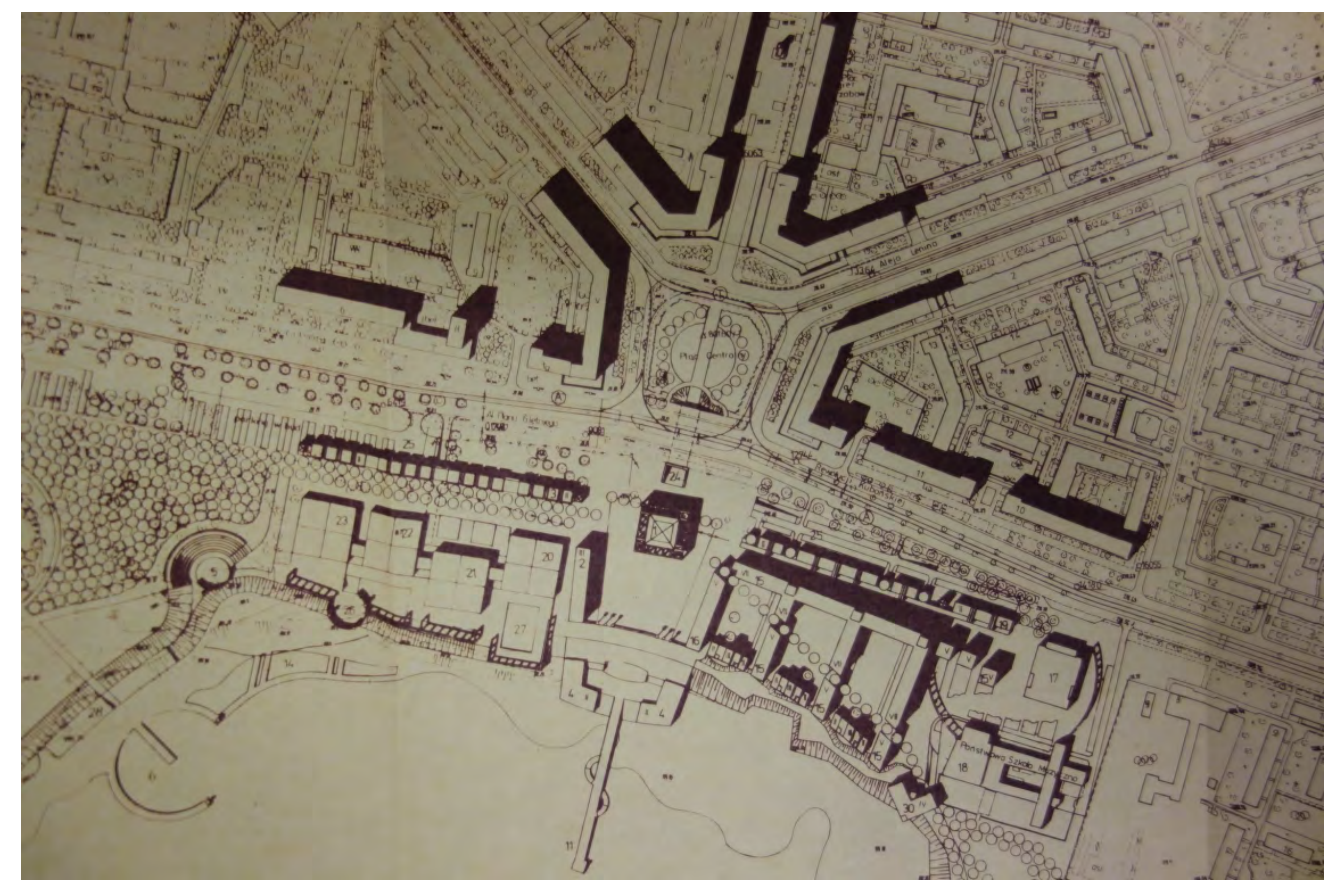

Figure 23: Na Skarpie Estate in Kraków-Nowa Huta, master plan, c. 1986 (Romuald Loegler et al.) in Archiwum Urzedu Miasta Krakowa, Binder Budownictwa i Architektury BA, "Na Skarpie - Zespół Mieszkaniowy", 1983-85.

$198 \times 132 \mathrm{~mm}(300 \times 300 \mathrm{DPI})$ 
Figure 24: Na Skarpie Estate, six-storey building, south elevation, dated April 1986, in Romuald Loegler, Residential Development Na Skarpie in Archiwum Urzedu Miasta Krakowa, Binder Budownictwa i Architektury BA, "Na Skarpie - Zespół Mieszkaniowy", 1983-85.

\section{$170 \times 87 \mathrm{~mm}(300 \times 300$ DPI $)$}




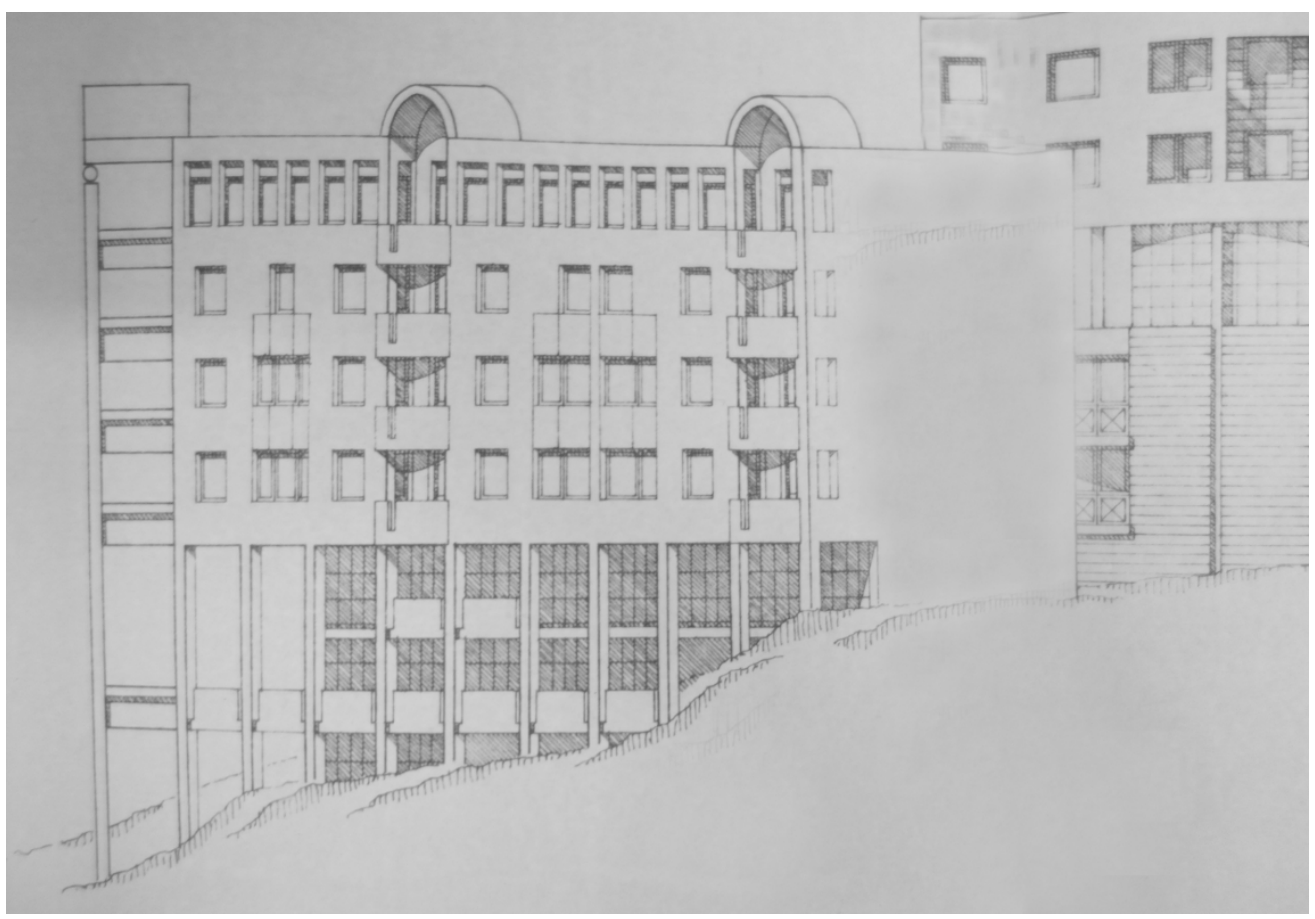

Figure 25: Na Skarpie Estate, building "on stilts," southwest elevation, dated April 1986 Romuald Loegler, Residential Development Na Skarpie in Archiwum Urzedu Miasta Krakowa, Binder Budownictwa i Architektury BA, "Na Skarpie - Zespół Mieszkaniowy", 1983-85.

$185 \times 128 \mathrm{~mm}(300 \times 300 \mathrm{DPI})$ 


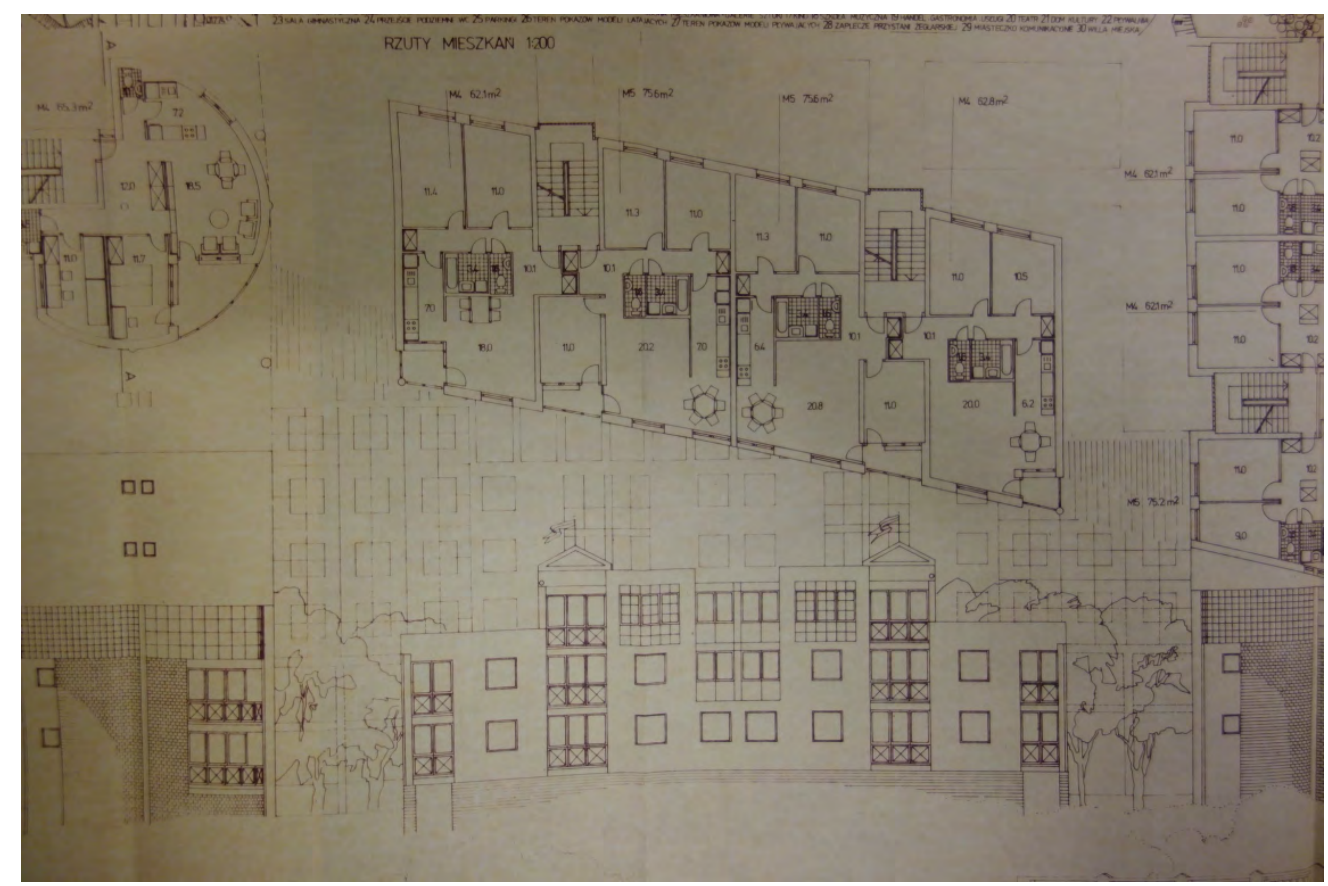

Figure 26: Flat plans in the Na Skarpie Estate, Romuald Loegler, Residential Development Na Skarpie in Archiwum Urzedu Miasta Krakowa, Binder Budownictwa i Architektury BA, "Na Skarpie - Zespół Mieszkaniowy", 1983-85.

$198 \times 132 \mathrm{~mm}(300 \times 300 \mathrm{DPI})$ 


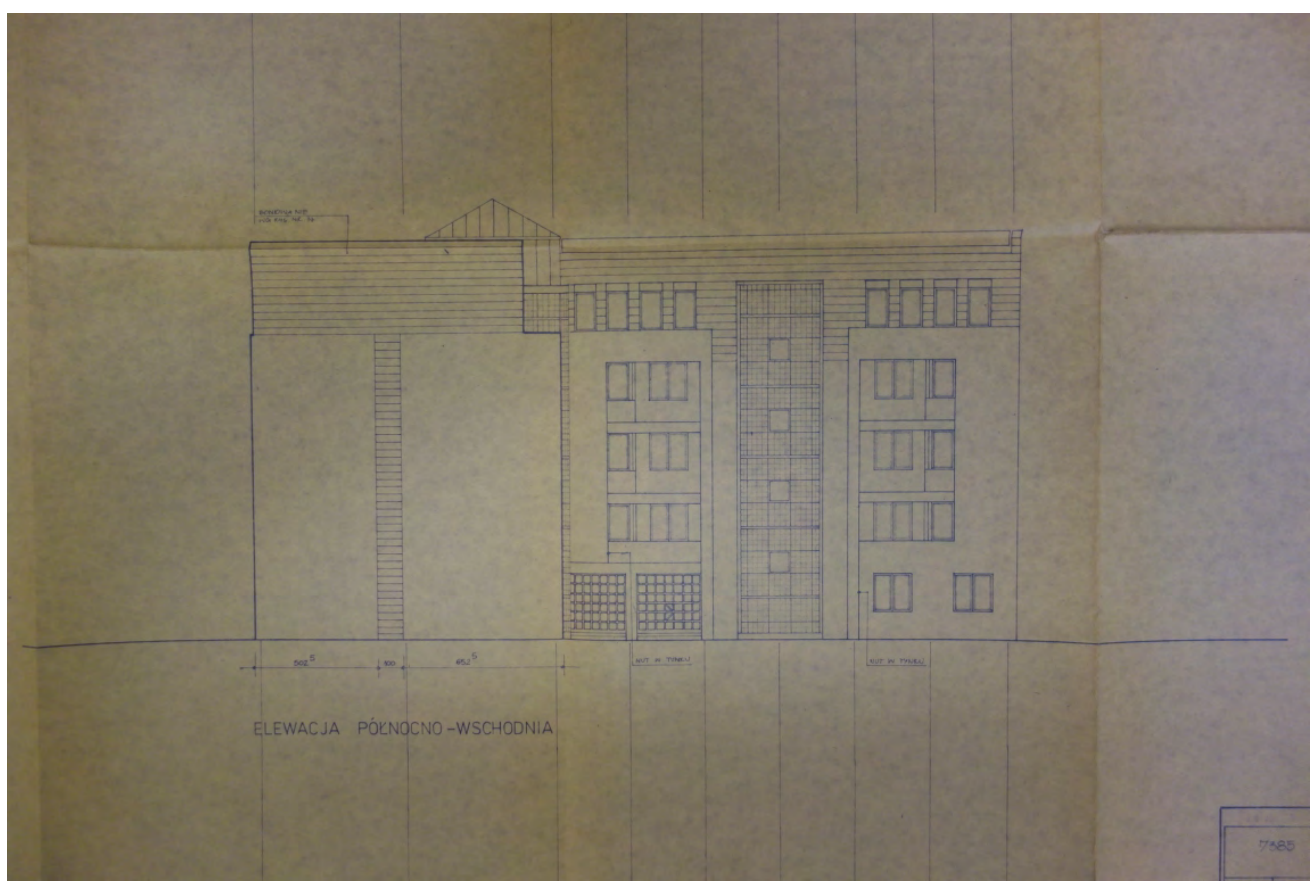

Figure 27: "Urban Villa" on Osiedle Centrum E no. 3, plan dated 1989, Romuald Loegler, Urban Villa in Archiwum Urzedu Miasta Krakowa, Binder Budownictwa i Architektury BA, "Na Skarpie - Willa Miejska", 1989_02.

$198 \times 132 \mathrm{~mm}(300 \times 300 \mathrm{DPI})$ 